\title{
HINT1 protein cooperates with cannabinoid 1 receptor to negatively regulate glutamate NMDA receptor activity
}

\author{
Ana Vicente-Sánchez, Pilar Sánchez-Blázquez, María Rodríguez-Muñoz and Javier Garzón*
}

\begin{abstract}
Background: G protein-coupled receptors (GPCRs) are the targets of a large number of drugs currently in therapeutic use. Likewise, the glutamate ionotropic $N$-methyl-D-aspartate receptor (NMDAR) has been implicated in certain neurological disorders, such as neurodegeration, neuropathic pain and mood disorders, as well as psychosis and schizophrenia. Thus, there is now an important need to characterize the interactions between GPCRs and NMDARs. Indeed, these interactions can produce distinct effects, and whereas the activation of Mu-opioid receptor (MOR) increases the calcium fluxes associated to NMDARs, that of type 1 cannabinoid receptor (CNR1) antagonizes their permeation. Notably, a series of proteins interact with these receptors affecting their responses and interactions, and then emerge as novel therapeutic targets for the aforementioned pathologies.

Results: We found that in the presence of GPCRs, the HINT1 protein influences the activity of NMDARs, whereby NMDAR activation was enhanced in $\mathrm{CNR}^{+/+} / \mathrm{HINT}^{-/-}$cortical neurons and the cannabinoid agonist WIN55,212-2 provided these cells with no protection against a NMDA insult. NMDAR activity was normalized in these cells by the lentiviral expression of HINT1, which also restored the neuroprotection mediated by cannabinoids. NMDAR activity was also enhanced in $\mathrm{CNR}^{-1-} / \mathrm{HINT}^{+/+}$neurons, although this activity was dampened by the expression of GPCRs like the MOR, CNR1 or serotonin 1A (5HT1AR).

Conclusions: The HINT1 protein plays an essential role in the GPCR-NMDAR connection. In the absence of receptor activation, GPCRs collaborate with HINT1 proteins to negatively control NMDAR activity. When activated, most GPCRs release the control of HINT1 and NMDAR responsiveness is enhanced. However, cannabinoids that act through CNR1 maintain the negative control of HINT1 on NMDAR function and their protection against glutamate excitotoxic insult persists.
\end{abstract}

Keywords: HINT1 protein, Cannabinoid receptor, NMDA receptor, Cortical neuron cultures, Excitotoxicity, Neuroprotection

\section{Background}

The glutamatergic $N$-methyl-D-aspartate (NMDA) receptor has a significant influence on the efficacy of neurotransmission and synaptic plasticity, and on processes such as learning and memory. The activation of this ionotropic receptor results in the permeation of $\mathrm{Ca}^{2+}$ ions, and it is positively regulated by certain $\mathrm{G}$ protein-coupled receptors (GPCRs) through the activity of PKC and Src $[1,2]$. Whilst, the Mu-opioid receptor (MOR) interacts with the NMDAR [3] positively regulating NMDAR

* Correspondence: jgarzon@cajal.csic.es

Neuropharmacology, Instituto Cajal, CSIC, Madrid E-28002, Spain calcium fluxes [4], the cannabinoid 1 receptor (CNR1) dampens the activity of this glutamate ionotropic receptor [5]. Notably, the regulation of MORs and of CNR1s on NMDARs activity requires the histidine triad nucleotidebinding protein 1 (HINT1), and in its absence these interactions are weakened to the extent that morphine no longer stimulates NMDAR activity and WIN55,212-2 fails to inhibit it [5-7].

The activation of CNR1s in the presynapse reduces the release of glutamate into the cleft and contributes to NMDAR hypofunction [8]. Nevertheless, CNR1s in the postsynapse also negatively regulate NMDAR function by
() Biomed Central

(c) 2013 Vicente-Sánchez et al.; licensee BioMed Central Ltd. This is an open access article distributed under the terms of the Creative Commons Attribution License (http://creativecommons.org/licenses/by/2.0), which permits unrestricted use,

distribution, and reproduction in any medium, provided the original work is properly cited. 
interfering with its signaling pathways [9]. However, cannabinoids prevent the endogenous increase of calcium through mechanisms related to the direct inhibition of NMDAR calcium influx $[9,10]$, as also suggested using whole-cell patch clamp recording techniques [11]. This mechanism would account for cannabinoid control of exogenous activators of NMDAR function. Thus, besides interacting with distant signaling pathways, cannabinoids can also directly affect the open probability of the NMDAR calcium channel. Immunocytochemical and ultrastructural studies demonstrated the presence of CNR1s in the postsynapse at both the spinal [12-14] and supraspinal level $[15,16]$, where they co-localize with NMDARs and PSD95 proteins [5,17]. Indeed, co-immunoprecipitation assays performed ex vivo on mouse cerebral cortical synaptosomes and in vitro studies with recombinant proteins revealed the association between CNR1s and NMDARs $[5,18]$. In the context of CNR1-NMDAR association, cannabinoids disassemble and inactivate CNR1-associated NMDARs through the co-internalization of NR1 subunits [5], and probably of surface NMDAR NR2 subunits as well [19].

HINT1 is a 126 amino acid protein of approximately $14 \mathrm{kDa}$ that belongs to the histidine triad (HIT) family, all members of which contain the HisXHisXHis sequence (where $\mathrm{X}$ is any hydrophobic amino acid). HINT1 binds zinc and purine nucleotides, and while it exists as a zinc-independent homodimer, zinc ions mediate the interaction between HINT1 and third party proteins $[6,20,21]$. This protein was initially referred to as a protein kinase $\mathrm{C}$-interacting protein $(\mathrm{PKCi})$ as it binds to and inhibits PKC function in a zinc-dependent manner [22]. However, this activity has since been relegated in favor of its enzymatic activity [23]. Notwithstanding, HINT1 appears to be implicated in a wide variety of physiological processes, some of these functions are independent of HINT1 enzymatic activity [24], such as DNA damage response pathways and tumor suppression pathways [25], repression of $\beta$-catenin signaling and transcriptional regulation [26], and regulation of cell endogenous calcium signaling [27]. Furthermore, there is evidence that at the plasma membrane HINT1 regulates GPCR function via PKC [7,28-31], and that it regulates the interaction of NMDARs with GPCRs like the MOR and CNR1 [5,6]. At the cell membrane, HINT1 exists as a homodimer and it behaves as a scaffold protein regulated by Redox processes that bring together different signaling pathways under the regulation of GPCRs $[32,33]$. In this way it is possible to reconcile the enzymatic activity of the HINT1 protein with its role as a switch in conveying information mediated by GPCR to different signaling pathways, e.g., glutamate NMDARmediated synaptic plasticity, $\beta$-catenin regulation, calcium signaling and DNA repair.
HINT1 associates directly with the cytosolic regions of NMDAR NR1 subunits and with those of certain GPCRs, recruiting a series of signaling proteins to the receptor environment [5,30-32]. Indeed, the cytosolic $\mathrm{C}$ terminal sequence of the MOR, and also that of CNR1, bind the cytosolic C1 segment of the NMDAR NR1 subunit, and HINT1 stabilizes this association [5,6]. Morphine challenge promotes the assembly and dis-assembly a series of signaling proteins at the MOR-HINT1 complex in order to enhance the activity of the NMDAR [30,31], which in turn negatively controls the effects of opioids [34,35]. The activation of the CNR1 has the opposite effect and it diminishes NMDAR activity. The negative regulation of NMDARs is particularly relevant because overactivation of NMDARs produces a series of perturbations that are associated with neurodegenerative diseases [36], mood disorders such as schizophrenia and depression [37,38], and neuropathic pain $[39,40]$. Indeed, cannabinoids are highly efficient in reducing calcium permeation mediated by NMDARs and in protecting neurons from the potential risks of excessive NMDAR activity [41,42]. Cannabinoid receptors are distributed throughout the central nervous system [43] and the CNR1 is present at high densities in presynaptic terminals [44], as well as in postsynaptic structures of spinal and supraspinal glutamatergic synapses $[12,14,15]$. As the HINT1 protein associates with the cytosolic regions of CNR1 [5,18,31], we sought to determine the effects of HINT1 on the cannabinoid-mediated negative control of glutamate NMDAR function. Our study indicates that in the absence of receptor activation, different GPCRs, including CNR1, collaborate with HINT1 proteins to reduce the sensitivity of NMDARs to stimulation. However, upon GPCR activation, cannabinoids maintain HINT1-mediated control over NMDAR activity and they protect against NMDA-associated excitotoxicity.

\section{Results}

Increased NMDA-induced neuronal injury and the absence of cannabinoid neuroprotection in $\mathrm{HINT}^{-1-}$ cultured cortical neurons

The exposure of neuronal-enriched E16 murine cortical cultures from wild-type (WT) $\left(\mathrm{HINT}^{+/+}\right)$and $\mathrm{HINT}^{-/-}$ mice to NMDA for $24 \mathrm{~h}$ resulted in a concentrationdependent decrease in cell viability, as measured by LDH release. In all cases, NMDA toxicity was greater in the knockout cells (Figure 1A,E,F). Pre-treatment or cotreatment with the cannabinoid agonist WIN55,212-2 reduced the toxicity of NMDA $(30 \mu \mathrm{M})$ in the WT cultures (Figure 1B,E,G). Furthermore, the effects of WIN55,212-2 against NMDA insult were abrogated upon treatment with the CNR1 antagonist SR141716A $(1 \mu \mathrm{M})$, which is consistent with CNR1-mediated neuroprotection. However, in the absence of HINT1, the positive effect of the cannabinoid agonist was absent (Figure 1B,F,H). 

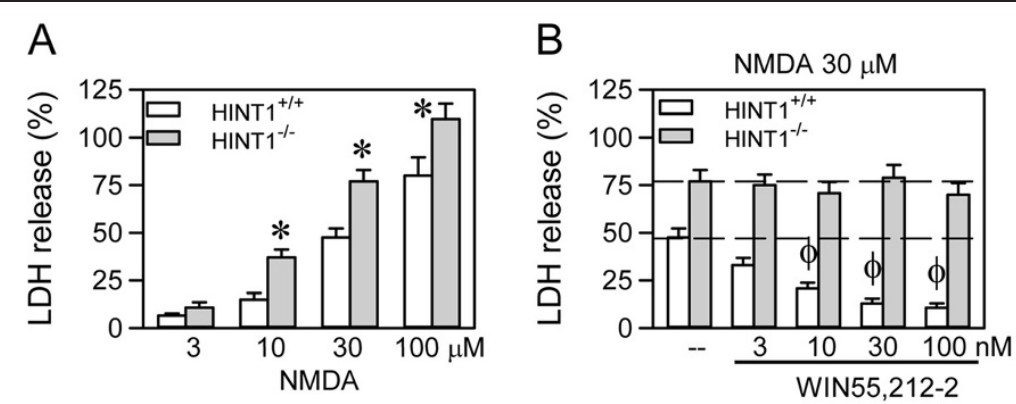

HINT1 ${ }^{+/+}$
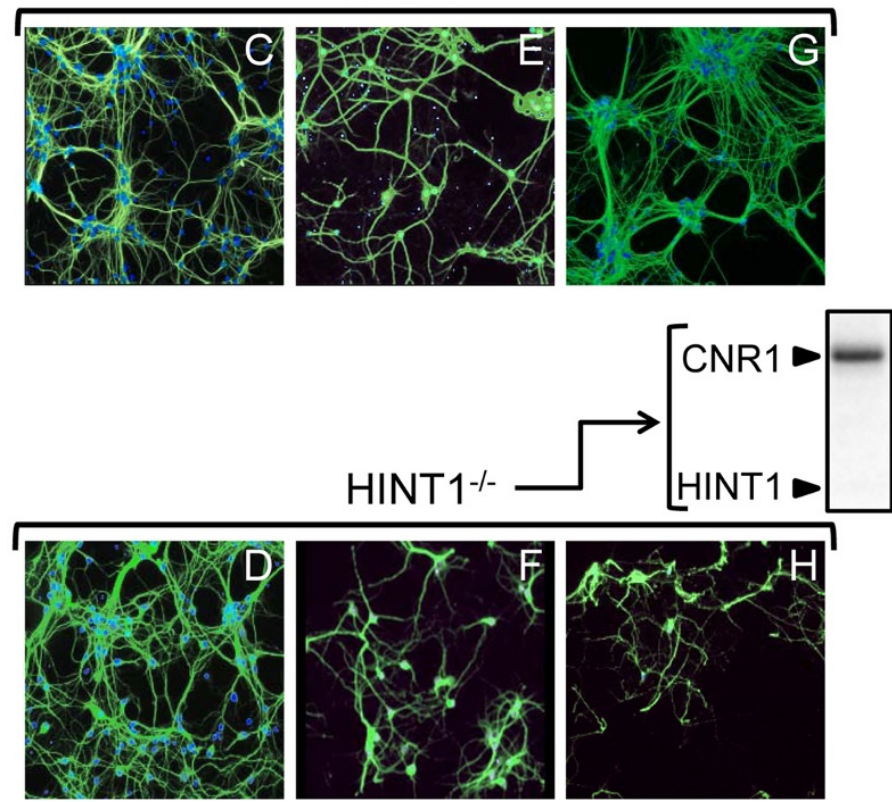

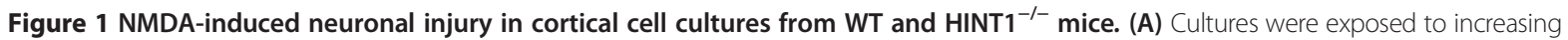
concentrations of NMDA for $24 \mathrm{~h}$. Cell death was measured by LDH efflux into the medium. The data shown represent the mean \pm S.E.M. from 20 wells per group. * Significant difference between WT and $\mathrm{HINT1}^{-1-}$ cultured neurons, $p<0.05$. (B) The cultures were exposed to a fixed concentration of $30 \mu \mathrm{M}$ NMDA for $24 \mathrm{~h}$ in the absence (--) or presence of increasing concentrations of the cannabinoid agonist WIN55,212-2. To eliminate the possible participation of cannabinoid receptor 2 (CNR2), the assay was conducted in the presence of $3 \mu \mathrm{M}$ of the CNR2 antagonist JTE907. Ф Significant difference compared to NMDA alone, $p<0.05$. (C-H) Fluorescence photomicrograph of cortical cell cultures immunolabelled with an anti-MAP2 antibody (Ab) (green) following treatment with vehicle (C and D), $30 \mu \mathrm{M} \mathrm{NMDA}$ (E and $\mathbf{F}$ ) or $30 \mu \mathrm{M}$ NMDA plus 100 nM WIN55,212-2 ( $\mathbf{G}$ and $\mathbf{H}$ ); the nuclei were counterstained with 4,6-diamidino-2-phenylindole. Inset: Immunodetection study of CNR1 (antibody C terminal sequence

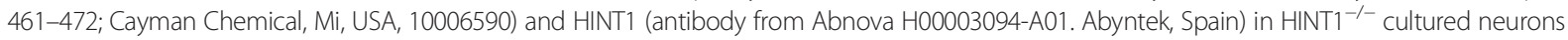
(40 $\mathrm{\mu g} / \mathrm{lane})$.

We then infected $\mathrm{HINT1}^{-/-}$cortical cultures with lentiviral vectors expressing the HINT1 protein. Transgene expression was significantly detected 3 days posttransduction (Figure 2A). After NMDA exposure for $24 \mathrm{~h}(30 \mu \mathrm{M})$, the viability of the $\mathrm{HINT}^{-/-}$neurons transduced with pLVTHM-HINT1 (0.1 to $3 \mu \mathrm{L} /$ well lentiviral particles) was greater than the viability of pLVTHM-transduced $\mathrm{HINT}^{-1-}$ neurons and WT $\mathrm{HINT1}^{+/+}$neurons (Figure 2B). Infection of $\mathrm{HINT1}^{-/-}$ neurons with $1 \mu \mathrm{L} /$ well of the lentiviral particles also restored WIN55,212-2-mediated neuroprotection against NMDA toxicity (Figure 3A,B,C).
The enhanced response of $\mathrm{HINT} 1^{-/-}$neurons to NMDAR activation

The function of NMDARs is linked to the activation of nNOS and the NO-mediated regulation of zinc metabolism (Figure 4) [5]. Certainly, the de-regulation of zinc homeostasis has been shown to contribute to neurotoxicity [45]. As the absence of HINT1 reduced cell viability in response to NMDA insult, we explored the possibility that NMDAR-mediated NO production and zinc release were regulated by HINT1. We first determined whether the endogenous content of zinc ions (both free ions plus those complexed to proteins) was comparable in membranes 


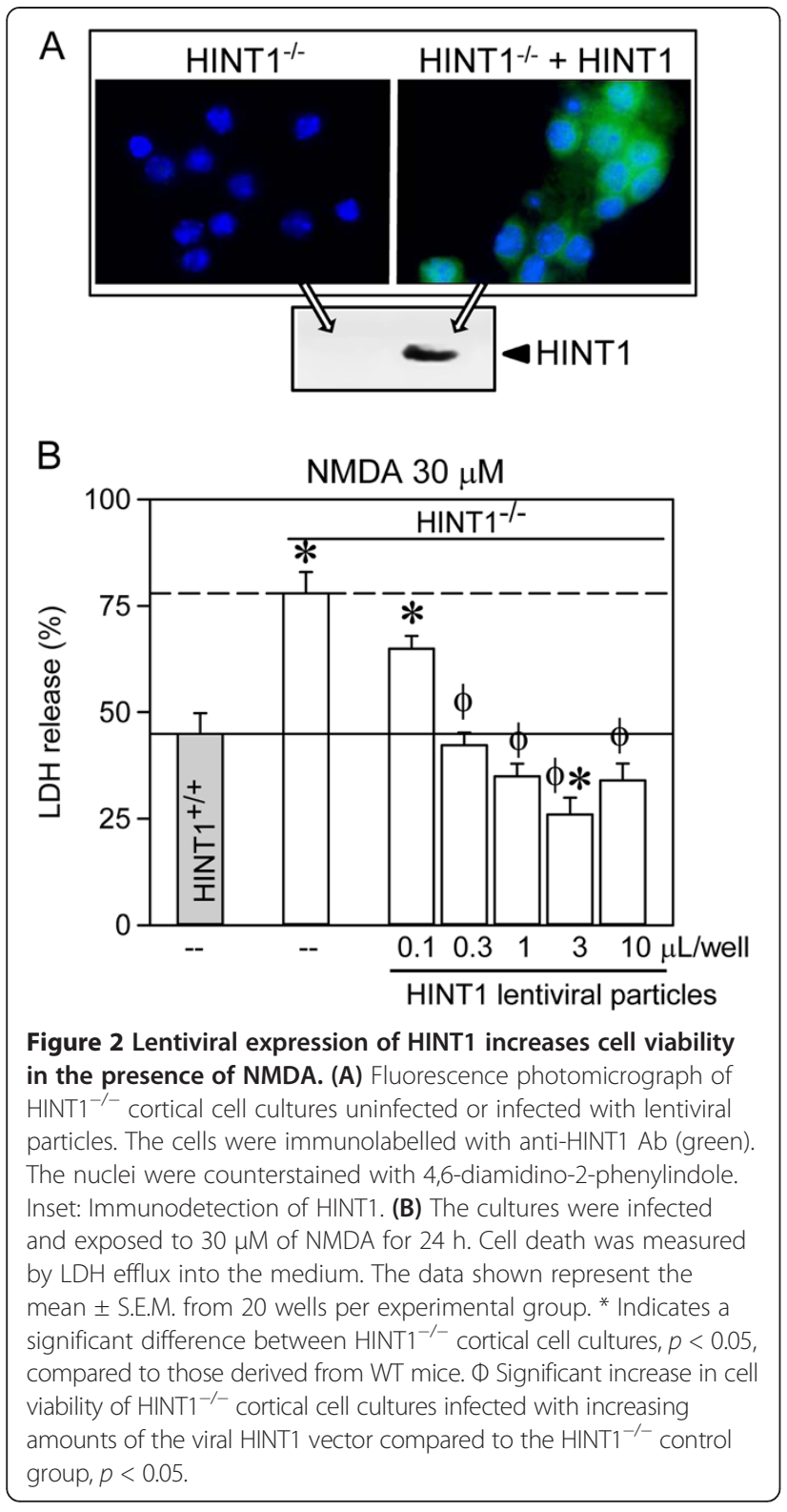

of cortical synaptosomes obtained from wild-type and $\mathrm{HINT}^{-/-}$mice (Figure 4A). Then, we evaluated the release of endogenous zinc in response to NMDAR activation. The incubation of mouse brain cortical slices with NMDA increased Newport Green fluorescence, a measure of zinc ion release from endogenous stores via nNOS/NO in response to NMDAR activity. NMDAR-mediated zinc release was attenuated by MK801 and prevented by NOS inhibition (Figure 4B). However, NMDA evoked a significantly greater mobilization of zinc ions in the absence of HINT1. This enhancement was not observed for morphine or WIN55,212-2, agonists of the MOR and CNR1, suggesting that HINT1 regulates the activity of NMDARs but not that of GPCRs (Figure 5).
To further investigate the effects of HINT1 on NMDAR function, whole-cell currents from CA1 pyramidal neurons were recorded in hippocampal slices from $\mathrm{HINT}_{1}^{+/+}$ and $\mathrm{HINT}^{-/-}$mice. Whereas the activity of synaptic NMDARs was only slightly increased in the preparations from $\mathrm{HINT}^{-/-}$mice, the amplitude of the spontaneous slow inward currents that are selectively mediated by the activation of extrasynaptic NMDA receptors was significantly higher in $\mathrm{HINT}^{-/}$mice than in WT mice (mean amplitudes: $-100.7 \pm 7.8 \mathrm{pA}, \mathrm{n}=60$ and $-64 \pm 5.7 \mathrm{pA}, \mathrm{n}=$ 40; in 10 and 8 neurons from HINT1 ${ }^{-/-}$and $\mathrm{HINT}^{+/+}$ mice, respectively). The identity of these NMDAR currents was confirmed by their sensitivity to the NMDAR antagonist D-AP5 [46-48]. To test whether these differences were specifically due to HINT1, we recorded the NMDAR-mediated currents using purified protein in the whole-cell recording pipette. The presence of HINT1 in the intracellular solution did not affect the WT neurons but reversed the changes observed in the transgenic mice (mean amplitude: $-70.6 \pm 8.1 \mathrm{pA}, \mathrm{n}=67$, from 8 neurons) (Figure 6A).

Compared to the HINT1 $1^{+/+}$controls, the HINT1 ${ }^{-/-}$ mice demonstrated increased markers of NMDAR function, such as CaMKII pThr286 autophosphorylation [49] and the phosphorylation of NR1 subunits on Ser897 [3], which are both facilitated by PKA activity (Figure 6B). Similarly, compared to the WT littermates, the HINT1 ${ }^{-/-}$ mice displayed higher PKA activity and greater PKAinduced CaMKII activation and NR1 C1 Ser897 phosphorylation in response to stress induced by the forced swimming test (Figure 6B). Thus, HINT1 negatively regulates NMDAR function and is neuroprotective against NMDA-induced excitotoxicity.

\section{GPCRs diminish NMDAR responsiveness via HINT1}

HINT1 is present in cortical cultures from mice deficient in CNR1 ( $\mathrm{CNR}^{-/-}$), and these cells were more sensitive to NMDA toxicity than cells from WT mice [42] (Figure 7). As the HINT1 protein interacts with the cytosolic regions of different GPCRs, including the CNR1, MOR, serotonin $5 \mathrm{HT} 1 \mathrm{~A}$ receptor and the dopamine D2 receptor [5-7,31], we determined whether these GPCRs might assist HINT1 to negatively regulate NMDAR function. With the exception of the CNR1, most GPCRs are absent from neurons in primary cultures that are established at this stage of ontogenesis (from E16 embryos), including the dopamine D2 receptors, serotonin $5 \mathrm{HT} 1 / 2$ receptors and MORs [50-52], and thus we forced their expression in these cells. Our results indicated that $\mathrm{CNR} 1^{-/-}$cortical cultures transfected with CNR1 receptors were much less sensitive to NMDA insult (Figure 7A,B vs D,E), and the expression of GPCRs in the $\mathrm{CNR}^{-/-}$cultured neurons during this stage of neural development also led to reduced NMDA toxicity. Thus, 5HT1A receptors and MOR significantly reduced 

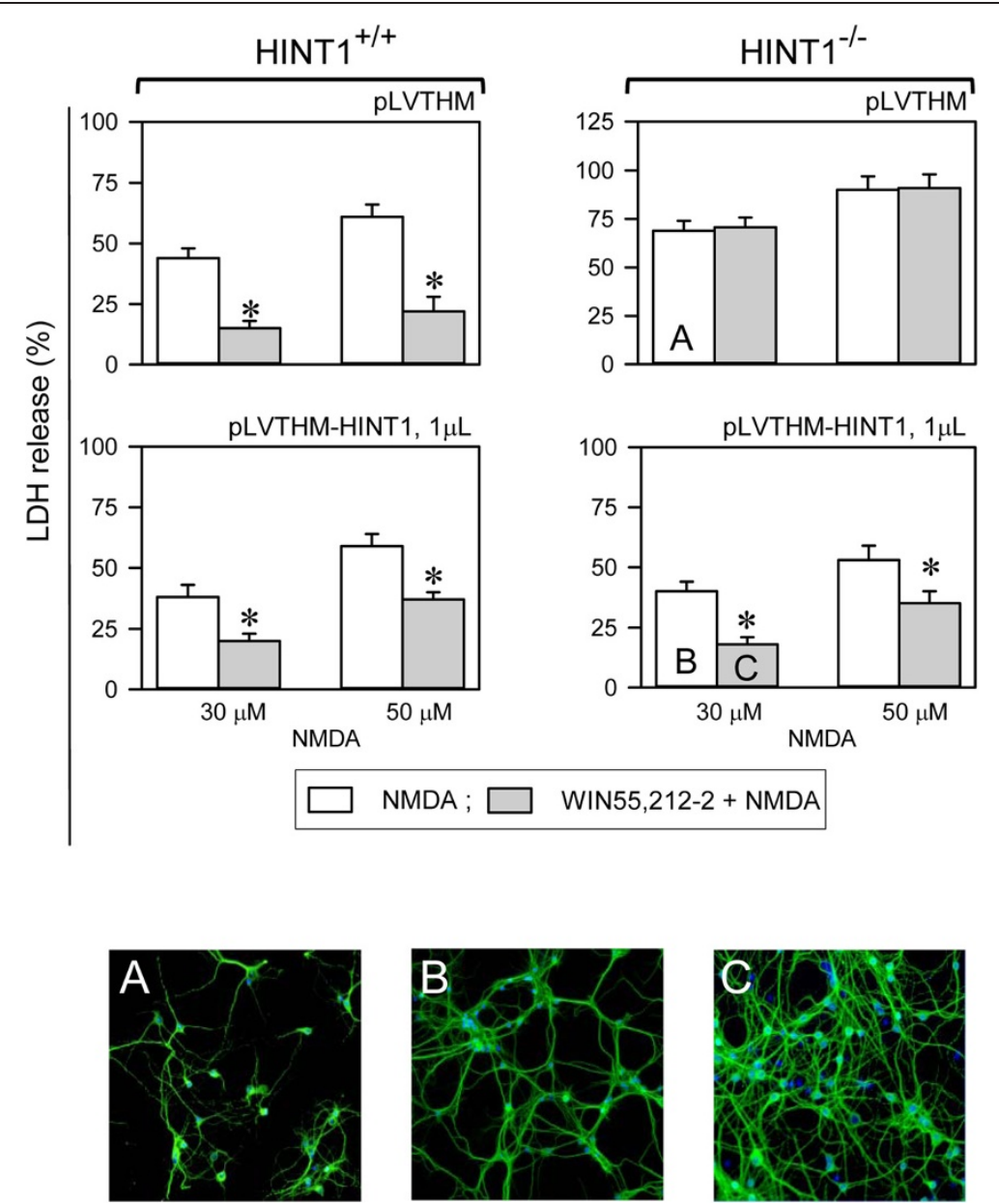

Figure 3 The effect of lentiviral expression of HINT1 on WIN55,212-2-mediated neuroprotection against NMDA insult. The cell cultures from $\mathrm{WT}$ and $\mathrm{HINT}^{-1-}$ mice were infected with 0.1 or $3 \mu \mathrm{L}$ of lentiviral particles and exposed to NMDA for $24 \mathrm{~h}$ in the absence or presence of 100 nM of WIN55,212-2. Cell death was measured by LDH efflux into the medium. The data shown represent the mean \pm S.E.M. from 20 wells per condition. * Significant difference compared to NMDA alone, $p<0.05$. Bottom: Fluorescence photomicrographs of NMDA-treated HINT1 ${ }^{-/-}$ cortical cell cultures (A) uninfected or infected with HINT1 lentiviral particles either (B) without or (C) with WIN55,212-2. The cells were immunolabelled with an anti-MAP2 Ab (green). The nuclei were counterstained with 4,6-diamidino-2-phenylindole.

NMDAR excitability. The D2Rs had the weakest effect on NMDAR activity (Figure 7), and this effect of the GPCRs was not modified by their respective antagonists (NMDA $30 \mu \mathrm{M}$, antagonists $10 \mu \mathrm{M}$ and \% LDH release as mean \pm SEM), WAY100135 (5HT1AR) $42 \pm 4$, naltrexone (MOR) $48 \pm 5$, L-741,626 (D2R) $70 \pm 6$, SR141716A (CNR1) $42 \pm$ $5, \mathrm{n}=3$ ). CNR1 agonists, such as WIN55,212-2, when used in the $\mathrm{nM}$ range were protective against NMDA excitotoxicity (Figure 1B). However, $1 \mu \mathrm{M}$ concentrations of the other GPCR agonists failed to provide protection (DPAT (5HT1AR) $49 \pm 4$, morphine (MOR) $59 \pm 5$, or quinpirole (D2R) $71 \pm 6, n=3$ ).

\section{HINT1 facilitates the association between MOR/CNR1 and} NR1 subunits

MOR and CNR1 associate with NR1 subunits of NMDARs [3,5], and the HINT1 protein stabilizes their interaction [5,53]. In synaptosomes from the adult mouse cerebral cortex, both MOR and CNR1 co-precipitated with the NR1 subunits, and this association was much weaker in $\mathrm{HINT}^{-1-}$ mice (Figure 8A). In cortical cultures from WT mice, the NR1 subunits co-precipitated with CNR1 and HINT1. In HINT1 ${ }^{-1-}$ neurons, the amounts of the NR1 subunits and CNR1 were similar to those in $\mathrm{HINT}^{+/+}$neurons. However, in the absence of HINT1, much less CNR1 co-precipitated with the NR1 subunits compared to the WT cultures. Furthermore, infection of $\mathrm{HINT1}^{-/-}$neurons with HINT1 lentiviral particles increased HINT1 expression, which resulted in the coprecipitation of CNR1 with the NR1 subunits (Figure 8B).

Our results further demonstrated that in WT $\mathrm{HINT}^{+/+}$ cells, the presence of certain GPCRs was sufficient to reduce the impact of NMDA insult and neuronal death (Figure 7). This effect was related to the association of 


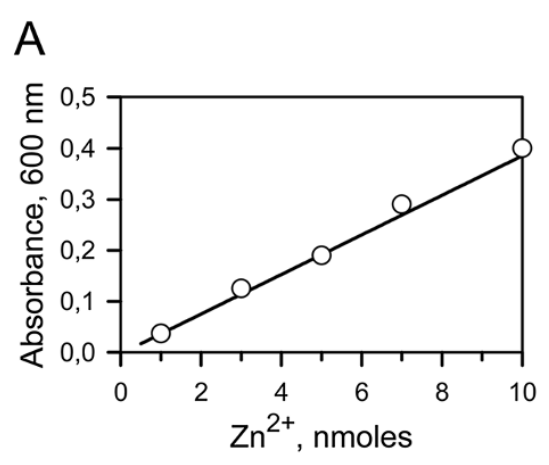

Released Zinc, nmol/mg membrane protein

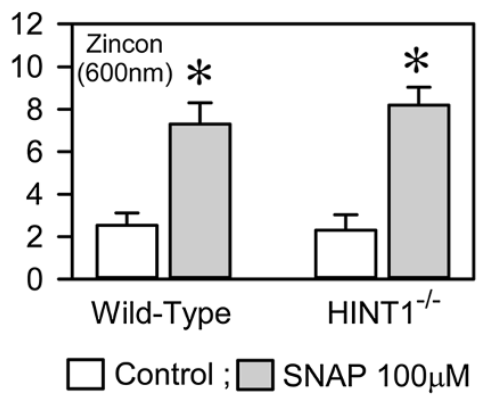

B
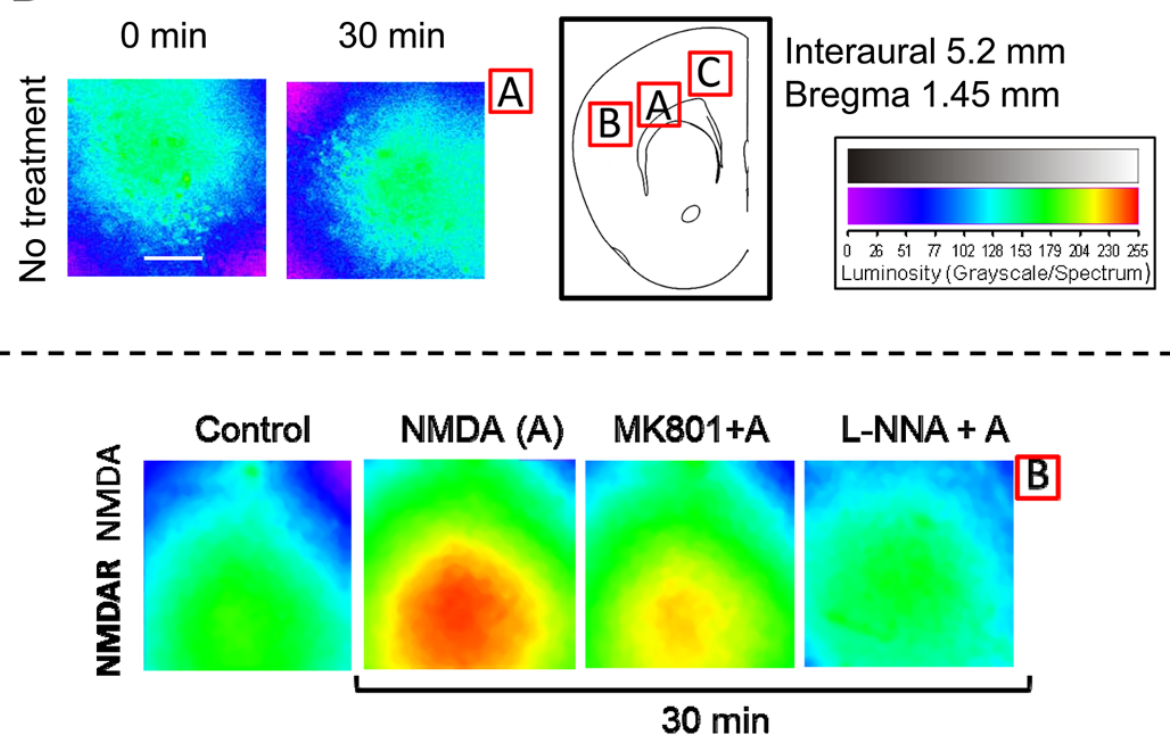

Figure 4 NMDAR-mediated nNOS/NO activation and zinc release. A: SNAP release of endogenous zinc from cortical synaptosome membranes obtained from wild-type and HINT1 ${ }^{-/-}$mice. SNAP $(100 \mu \mathrm{M})$ was added to cortical membranes and the assay was carried out at RT, as described [30]. Left panel: Calibration curve for Zincon detection of $\mathrm{Zn}^{2+}$. Right panel: The NO donor was incubated with the membranes for $30 \mathrm{~min}$ and Zinc release was monitored by its complexing with the reporter (zinc chelator, Zincon). The absorbance at $600 \mathrm{~nm}$ was recorded at RT on a BioChrom Ultrospec 2100 spectrophotometer (Cambridge, UK) and the data represent the mean \pm SEM of three independent assays. *Significantly different from the respective control group (without SNAP), $p<0.05$. SNAP produced comparable release of zinc ions from wild-type and $\mathrm{HINT}^{-1-}$ synaptosome membranes. B: NMDAR-mediated production of $\mathrm{NO}$ and the subsequent release of zinc ions from endogenous stores. The spontaneous endogenous zinc release was determined in Control (untreated) sections. The data shown were obtained at 30 min post-treatment. The effect of NMDAR activation on zinc mobilization was then studied. Control: baseline vehicle; A stands for the agonist NMDA used at $3 \mu \mathrm{M} ;$ MK801+A = $3 \mu \mathrm{M}$ MK801 (NMDAR antagonist) + $3 \mu \mathrm{M}$ NMDA; L-NNA+A = $10 \mu \mathrm{M}$ L-NNA (NOS antagonist) + $3 \mu \mathrm{M}$ NMDA. The images were color indexed and presented in pseudocolor.

these receptors (MOR and CNR1 with the NR1 subunits) via HINT1. Thus, we next investigated whether the dissociation of NMDARs from MORs control would lead to an increased responsiveness to their activators, which was observed in cultured neurons in the absence of HINT1 or CNR1. Opioids, such as morphine and DAMGO, promote PKC-mediated dissociation of MOR from NR1 subunits [3]. In these circumstances, intracerebroventricular (icv) injection of NMDA to WT mice activated the NMDAR effector CaMKII to a much greater extent than in mice that were not treated with these opioids and showed MOR-NR1 association (Figure 8C).

Neuropathic pain is accompanied with an excess of glutamate activity and the overactivation of NMDARs [8]. Thus, we studied the stability of the MOR-NMDAR complex in mice suffering from chronic constriction injury (CCI), a model of neuropathic pain, for 7 days. We found that the activity of the NMDAR/CaMKII pathway was enhanced, and MOR was not associated with the NR1 subunits (Figure 8C). 


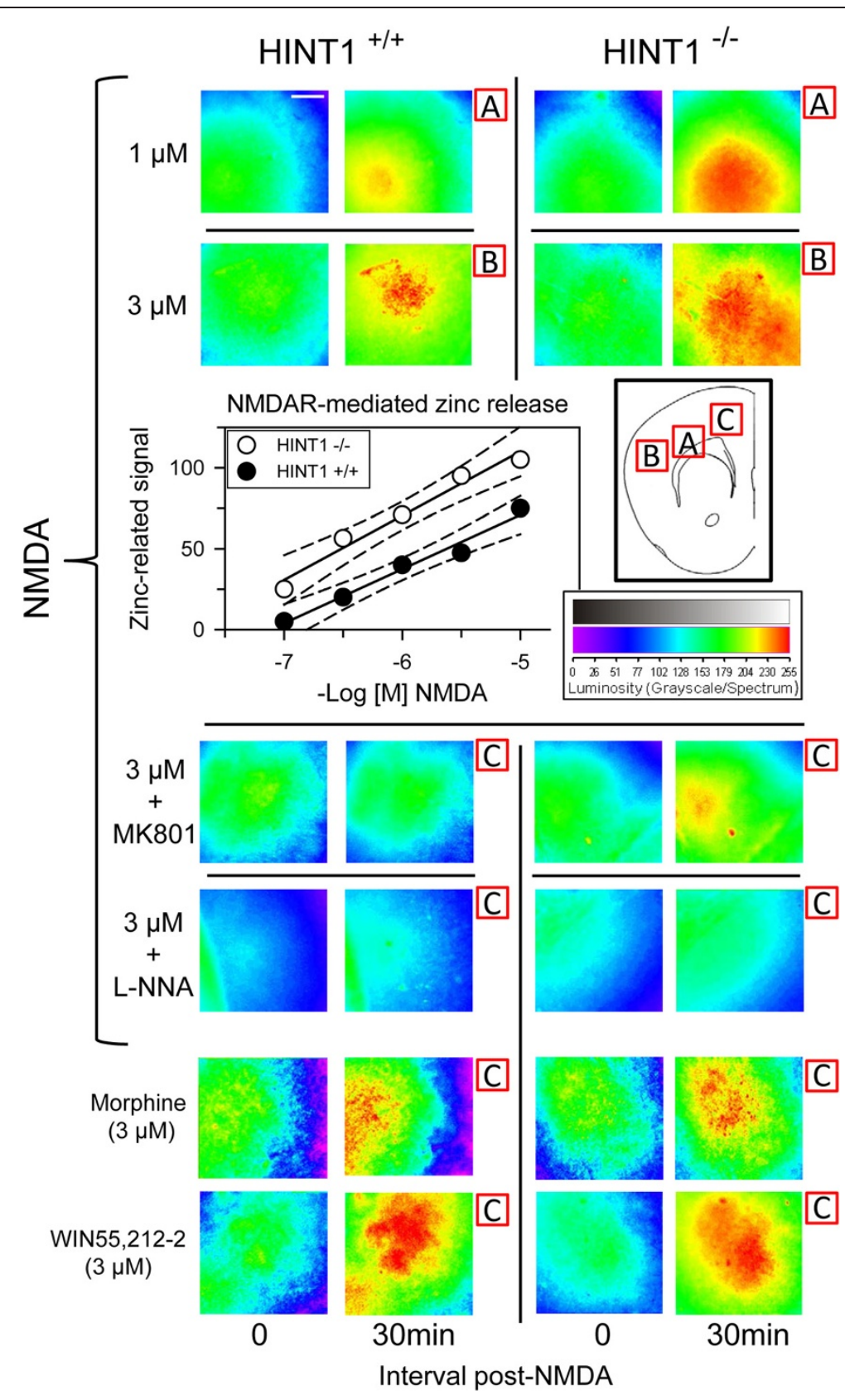

Figure 5 The absence of HINT1 increases NMDAR-mediated NO production and zinc mobilization in response to NMDA. Coronal mouse frontal cortex slices from WT and HINT1 ${ }^{-1-}$ mice were preloaded with Newport Green diacetate, and fluorescent images were obtained using a $10 \times 0.4$ HC PL APO objective (excitation, 488; emission, 498-520). The cortical regions studied are indicated as A, B or C, and the data shown were obtained 30 min post-treatment. NMDA was used at the concentrations indicated in the inset, and images for $1 \mu \mathrm{M}$ and $3 \mu \mathrm{M}$ are shown. Morphine and WIN55,212-2 were used at $3 \mu \mathrm{M}$. The NMDAR antagonist MK801 was used at $3 \mu \mathrm{M}$, and the NOS inhibitor L-NNA was used at 10 $\mu \mathrm{M}$. For each treatment, the assays for wild-type (WT) and $\mathrm{HINT1}^{-1-}$ cortical slices were performed during the same run, and the images obtained were color-indexed and presented in pseudocolor [31]. Scale bar $=500 \mu \mathrm{m}$. The assay was typically repeated 3 times, and the results were always comparable. Representative images are shown. Inset: Linear regression and 95\% confidence intervals of the zinc release promoted by increasing concentrations of NMDA in cortical slices from WT and $\mathrm{HINT}^{-/-}$mice.

\section{Discussion}

Our study showed that HINT1 inhibits the responsiveness of glutamate NMDARs to exogenous and endogenous activators when released during a mild stress response.
This inhibition seems to be mediated by the interaction of HINT1 proteins with NMDAR NR1 subunits and requires the cooperation of non-activated GPCRs, such as CNR1, MOR or 5-HT1AR. The absence of HINT1 weakened the 

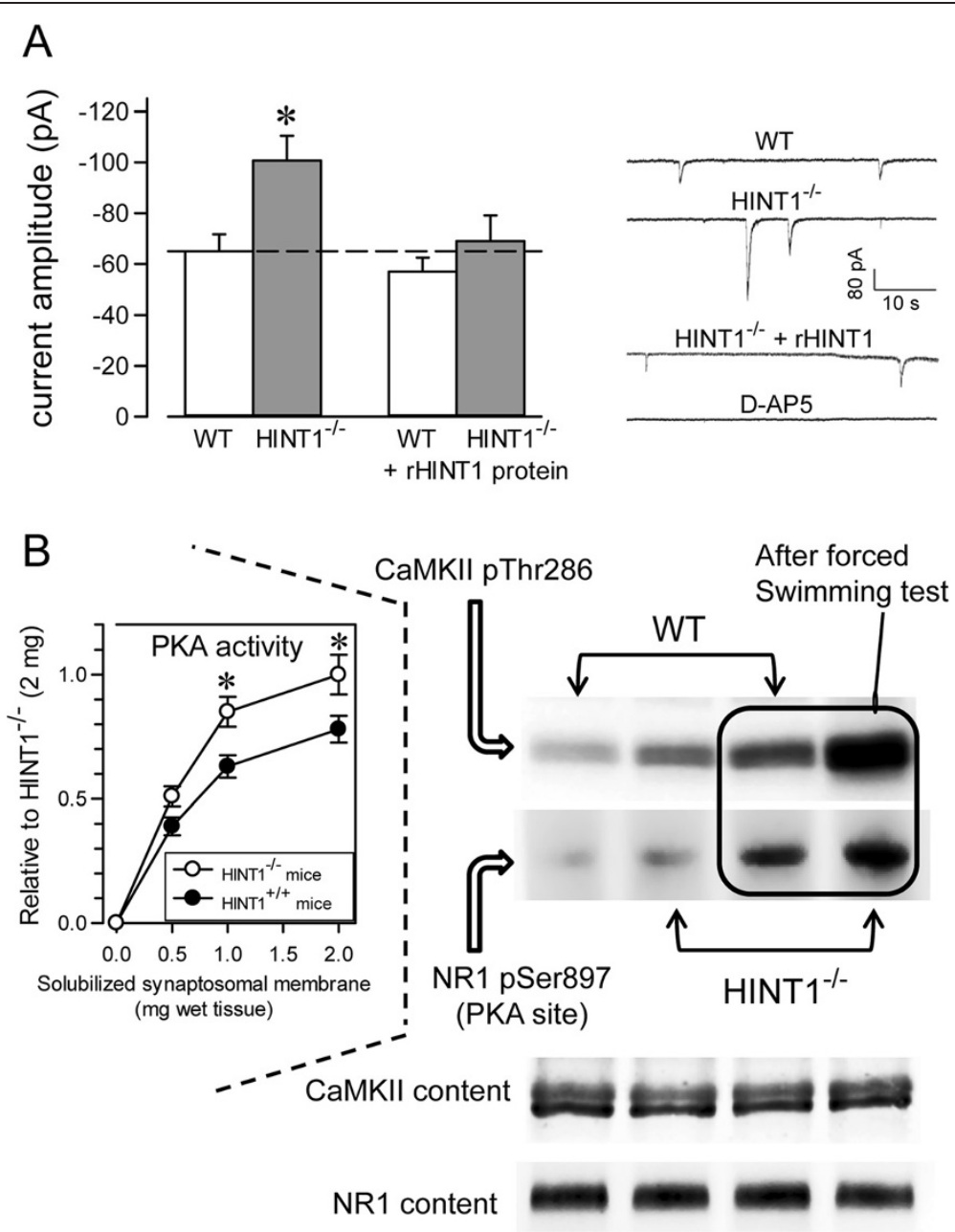

Figure 6 The effects of HINT1 on the responsiveness of NMDAR. (A) Spontaneous NMDAR-mediated currents in CA1 pyramidal neurons from WT and $\mathrm{HINT}^{-1-}$ mice. The mean amplitudes of the spontaneous, NMDAR-mediated currents recorded in neurons from WT and HINT1 ${ }^{-1-}$ mice in control conditions and when HINT1 was included in the solution of the recording pipette. The data are represented as the mean \pm S.E.M. from WT $(n=12)$ and $\mathrm{HINT1}^{-/-}(\mathrm{n}=28)$ mice. * Significant difference $p<0.05$. Representative whole-cell currents recorded from CA1 pyramidal neurons from WT and $\mathrm{HINT}^{-1-}$ mice with the internal control solution and neurons recorded with HINT1 added to the internal solution. Higher amplitudes of the NMDAR-mediated slow inward currents were observed in HINT1 ${ }^{-/}$mice relative to WT samples, which reverted in the presence of HINT1. The NMDAR antagonist D-AP5 $(50 \mu \mathrm{M})$ abolished these currents. (B) The effect of mild stress induced by the forced swimming test on NMDAR activity in WT and HINT1 ${ }^{-1-}$ mice. Thr286 CaMKIl autophosphorylation and PKA-mediated Ser897 NR1 phosphorylation were measured in the controls and mice exposed to the test. Inset: PKA activity of cortical synaptosomes in WT and HINT1 ${ }^{-/-}$mice.

association between NMDAR NR1 subunits and GPCRs, enhancing the responses of NMDARs to activators. The activation of most GPCRs promotes that of NMDARs and for the MOR, this is accompanied by the separation of MOR-HINT1 complex from the NMDAR NR1 subunit. Therefore, several GPCRs restrain the activity of NMDARs, although this control can be released in response to their activation, thereby contributing to NMDAR signaling. By contrast, the activated CNR1 maintains a negative influence on NMDAR gating, which facilitates its protective effect against NMDA excitotoxicity. Thus, the HINT1 protein emerges as an essential regulator of these GPCR-NMDAR interactions.
Synaptic NMDARs are mostly targeted to the postsynaptic region of glutamatergic synapses, where they structurally organize (and spatially restricted) into large macromolecular signaling complexes composed of scaffolding and adaptor proteins. These structures physically link the NMDAR to kinases, phosphatases, GPCRs and other signaling molecules [54,55]. Moreover, these interactions between GPCRs and NMDARs may occur more frequently than suspected, and physical interactions between the dopamine D1 receptor, group I metabotropic glutamate receptor (mGlu5a), MOR or CNR1 and the C1 segment of NMDAR NR1 subunits have also been reported $[3,5,56,57]$. 


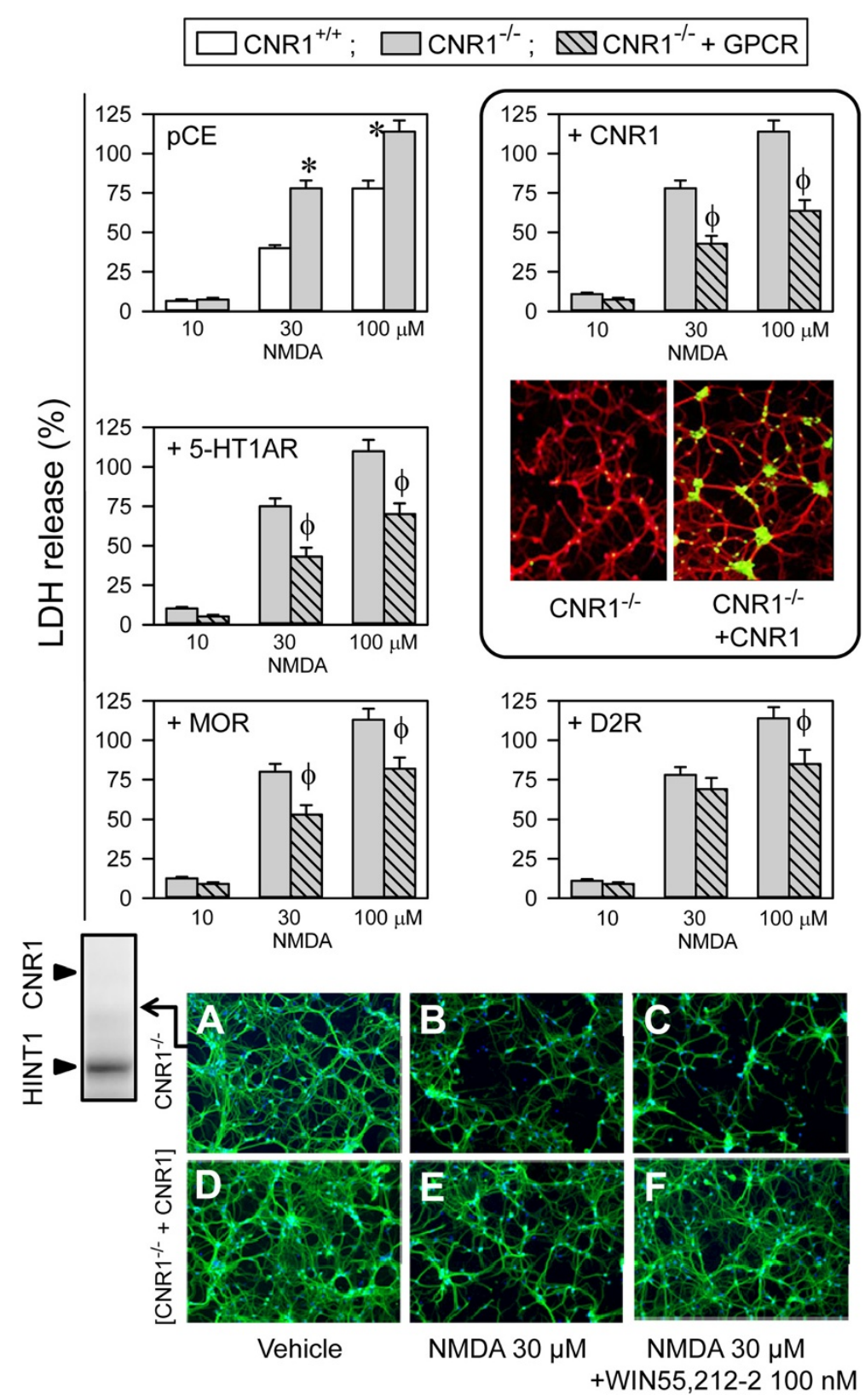

Figure 7 The expression of GPCRs reduces NMDAR activity. Cortical cell cultures from WT and CNR1 $1^{-1-}$ mice were exposed to NMDA for $24 \mathrm{~h}$. * Significant difference compared to WT cultured neurons, $p<0.05$. Cell death induced by NMDA was also determined in cultures transfected with CNR1, serotonin receptor type 1A (5HT1AR), Mu-opioid receptor (MOR) and dopaminergic receptor type 2 (D2R). $\Phi$ Significant difference in the $C N R 1^{-1-}$ cultured neurons that were not transfected with the corresponding GPCR, $p<0.05$. The data shown represent the mean \pm S.E.M. from 12 wells per experimental group. Inset to CNR1 group: Fluorescence photomicrograph of $\mathrm{CNR}^{-/-}$cortical cell cultures showing the expression of transfected CNR1 using Abs against CNR1 (green) and MAP2 (red). The nuclei were counterstained with 4,6-diamidino-2-phenylindole. Bottom: The cells were immunolabelled with an anti-MAP2 Ab (green) and assayed following treatment with vehicle (A and $\mathbf{D}), 30 \mu \mathrm{M}$ of NMDA (B and $\mathbf{E}$ ) or $30 \mu \mathrm{M}$ of NMDA plus 100 nM of WIN55,212-2 (C and $\mathbf{F}$ ). The expression of HINT1 in the $\mathrm{CNR}^{-/-}$cortical cell cultures is shown.

In brain synaptosomes from HINT1 $1^{-/-}$mice, the quantities of the NR1 subunits, CNR1, MOR and zinc content were similar to those in WT mice. However, in the absence of HINT1 the association between these GPCRs and the NR1 subunits weakened, and consequently, NMDARs mobilized more zinc ions from endogenous stores than in the WT controls. Thus, HINT1 stabilizes the coupling of CNR1s with NMDAR NR1 subunits that is required for cannabinoids to dampen NMDAR activity. Indeed, in $\mathrm{HINT}^{-/-}$cortical neurons NMDAR responsiveness is enhanced and the presence of CNR1 was not sufficient to inhibit this activity, with WIN55,212-2 failing to 

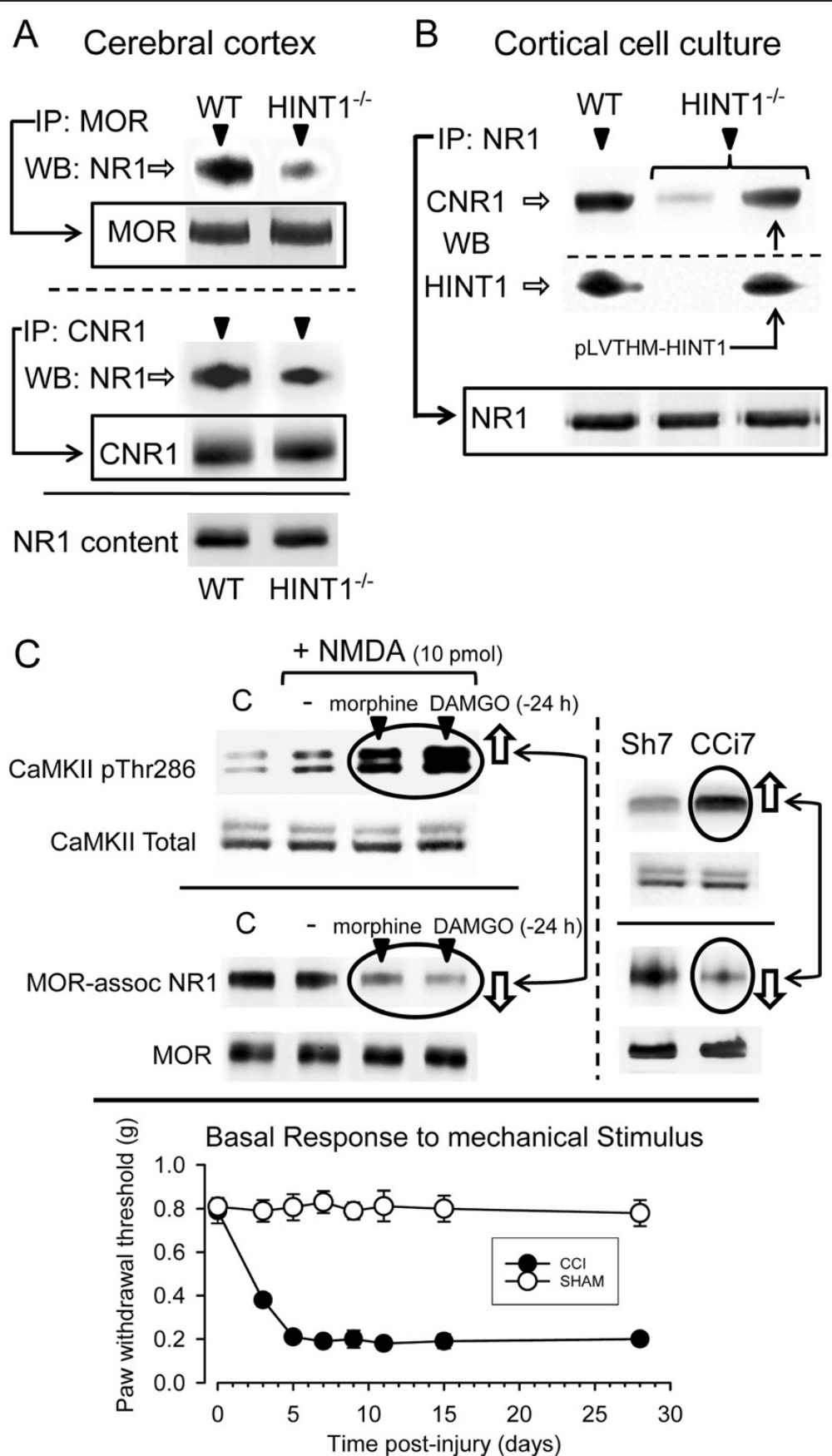

Figure 8 MOR and CNR1 associate with the NR1 subunits via HINT1: Implications for NMDAR activity. (A) The association of GPCRs, MOR and CNR1 with the NMDAR NR1 subunits is dependent on HINT1. The GPCRs were immunoprecipitated from solubilized mouse brain cortical synaptosomes from WT and HINT1 ${ }^{-1-}$ mice, and the proteins that co-precipitated with the NR1 subunits were analyzed by western blot. (B) The association of CNR1 with NR1 in WT and $\mathrm{HINT}^{-{ }^{--}}$cortical cell cultures uninfected or infected with $10 \mu \mathrm{L} /$ well of HINT1 ${ }^{-/-}$lentiviral particles. The presence/absence of HINT1 was determined, and the co-precipitates of the NR1 subunits and CNR1 were then assessed by immunoprecipitation and western blot. For each determination, cells from 10 wells were pooled, and the assay was repeated twice with identical results. (C) Opioid agonists promoted a higher level of responsiveness of the NMDAR by inhibiting the association between MOR and NR1. Morphine or DAMGO was icv-injected into the mice $24 \mathrm{~h}$ prior to the analysis of MOR/NMDA NR1 association and CaMKIl activating autophosphorylation on Thr286. At 7 days post-surgery, the mice from the CCI neuropathic pain group displayed increased pThr286 CaMKII and reduced MOR-NR1 association compared to the sham-operated controls. Changes of Mechanical Withdrawal Threshold. Following ligation, animals developed significant mechanical allodynia by day 3 that remained until day 21. Naïve control and sham - operated mice failed to exhibit mechanical allodynia. Data are mean \pm SEM. ${ }^{*} P<0.05$ vs. sham-operated group, ANOVA, followed by the Student-Newman-Keuls test (SigmaStat, SPSS Science Software, Erkrath, Germany) $p<0.05$. 
protect against cell death upon a NMDA insult [5]. In electrophysiological studies, hippocampal preparations from $\mathrm{HINT1}^{-/-}$mice exhibit increased extrasynaptic NMDAR current activity. Whereas synaptic NMDARs contribute to neuroprotection, stimulation of extrasynaptic NMDARs promotes cell death and a perturbation in this balance is currently believed to contribute to the etiology of neurodegenerative diseases [58]. Mood disorders, like mania, concur with altered NMDAR function, and bipolar disorder patients have fewer glial and neuronal cells $[59,60]$. Interestingly, when evaluated in the battery of conventional behavioral tests, $\mathrm{HINT1}^{-/-}$mice displayed manic-like behavior [61].

The activation of several GPCRs triggers that of the associated NMDARs via PKC/Src, a signaling mechanism that in certain situations negatively influences the activity of the GPCR itself, as described for the MOR [33]. The activity of the NMDAR within this regulatory loop must be tightly controlled to prevent the consequences of its de-regulation. By contrast, it is the activity of the NMDARs themselves that makes the demands on the endogenous cannabinoid system to control their calcium currents [62]. Therefore, the association of CNR1s with NR1 subunits through HINT1 proteins persists during NMDAR activation, and cannabinoids then exert negative control on the NMDARs' activity [5]. The differences that GPCRs display in the regulation of NMDARs is apparently unrelated to the class of $\mathrm{G}$ proteins they regulate, since while D1 regulates Gs/Gq [63], the MOR, CNR1, D2R and 5HT1A regulate Gi/o, and Gq couples to MOR, CNR1, 5HT2A [18,64-66]. It is possible that the association of the HINT1 protein with the GPCR determines the relation of the latter with the NMDAR. Several GPCRs bind the HINT1 protein through their cytosolic regions, such as the MOR, CNR1, 5HT1AR, 5HT2AR, muscarinic M2 and M4 receptors, $\alpha 2$ Adrenergic receptor, dopamine D2 receptor [31], D1 receptor (unpublished observation), mostly through the $\mathrm{C}$ terminal or third internal loop. Under physiological conditions, the resting CNR1 (as well as GPCRs like the MOR or the 5HT1A receptor) interact with HINT1 proteins to downregulate the activity of NMDARs, thereby restraining the overall NMDAR currents that could otherwise promote irreversible neuronal damage. Thus, in the context of NMDAR regulation by GPCRs, HINT1 emerges as an essential protein to protect against neuronal damage.

We have characterized the dynamics of MOR-HINT1 and CNR1-HINT1 associations with NMDARs in terms of receptor activation, identifying critical differences $[5,6]$. Opioids like morphine activate PKC, which disrupts the association of MOR-HINT1 with NMDAR NR1 subunits. However, when activated NMDARs recruit CaMKII activity, this increases their association with CNR1s and this is a relationship that is then further enhanced by PKC.
These kinases remove certain proteins, probably RGS-Rz proteins [6], from the CNR1-bound HINT1 protein, thereby promoting its binding to NR1 subunits. CaMKII plays different roles in CNR1 and MOR regulation, and whereas this kinase activity is implicated in MOR desensitization [67], in the CNR1-HINT1 environment it prevents the action of PKC on the NR1 C1 segment that would separate both receptors. Those GPCRs that enhance NMDAR function through the activation of PKC, intracellular $\mathrm{Ca} 2+$ release and Src activation, also promote serine phosphorylation of NR1 C1 $[1,4,68]$, comparable to that which occurs with the MOR. For other receptors that couple to and inhibit NMDARs, it would be necessary to address the molecular mechanisms behind their effects and to compare them with those of CNR1s.

The complex GPCR-HINT1 can interact with the C1 segment of NMDAR NR1 subunits [5] and this interaction reduces the gating of the tretrameric ionotropic receptor. The regulation of calcium fluxes permeating the NMDAR is complex and results from an interplay between different systems. Glutamate, glycine and D-serine bind to the extracellular domains of the NR1 and NR2/3 subunits, which augments calcium transit. Zinc ions co-released with glutamate reach micromolar concentrations in the cleft and they diminish the responsiveness of NMDARs to activation [69], these zinc ions displaying a higher affinity for NR2A subunits than NR2B subunits [70]. The sensitivity of the NMDAR to extracellular stimuli is regulated by the serine, threonine and tyrosine phosphorylation/dephosphorylation of cytosolic residues on the NR1/2 subunits [2,71]. By contrasts, PKC phosphorylates the NR1 subunits, which blocks the binding of negative regulators [72,73], and Src acts on the NR2A/B subunits to remove the tonic inhibition of extracellular zinc [74], resulting in an increase in the entry of extracellular calcium. The protein phosphatase calcineurin reverses the phosphorylation of the regulatory $\mathrm{C} 1$ region of the NR1 subunits and it plays an important role in the inactivation of NMDARs [75], probably favoring the binding of negative regulators. Moreover, the striatal-enriched protein tyrosine phosphatase (STEP) reverses the Srcmediated upregulation of NMDAR activity [76].

The control of NMDAR function is also achieved by direct physical interactions with third party proteins like calmodulin (CaM) and probably GPCR-HINT1. The calcium-dependent inactivation (CDI) of NMDARs is a negative feedback response that downregulates the gating of NMDAR channels and the calcium-binding protein CaM plays a key role in this response. The cytoskeletal protein $\alpha$-actinin 2 interacts with the $\mathrm{C} 0$ region of the NR1 subunits and calcium-activated $\mathrm{CaM}$ promotes $\mathrm{CDI}$ by releasing the NMDAR complex from the cytoskeleton. The NR1 $\mathrm{C} 1$ segment binds $\mathrm{Ca}^{2+}-\mathrm{CaM}$ rather than $\mathrm{CaM}$, and this binding reduces the "open" probability of the 
NMDAR-channel [77-79]. In addition, GPCR-activated PKC phosphorylates the C1 region at Ser890 and Ser896, and it blocks $\mathrm{Ca}^{2+}$-CaM binding [80,81], thereby promoting NMDAR activity. Thus, when coupled to nonactivated GPCRs HINT1 binds to this C1 region of the NR1 subunits and like $\mathrm{Ca}^{2+}-\mathrm{CaM}$ it inhibits NMDAR function [5] present study. In this context, the activation of GPCRs like the MOR and mGlu1 $\alpha$ enhances NMDAR activity in a PKC-dependent manner, which releases GPCRHINT1 inhibition and prevents the binding of $\mathrm{Ca}^{2+}-\mathrm{CaM}$ by acting on serines in the NR1 C1 domain, and both these effects increase the "open" probability of the calcium channel $[3,4,80]$.

In the $\mathrm{CCI}$ animal model of neuropathic pain in which NMDARs are more sensitive to glutamatergic activation, these receptors were separated from the MOR and then released from the control of HINT1. An interesting observation is that cerebral ischemia induces the accumulation of dopamine, serotonin and other neurotransmitters that contribute to neuronal death [82]. Accordingly, MOR antagonists, dopaminergic or serotonergic nerve depletors and glutamate antagonists prevent or reduce the brain injury that results from experimental heatstroke [83,84]. While antagonists targeting MOR or 5HT2AR protect against heatstroke, agonists of CNR1, the delta opioid receptor (DOR), 5HT1AR or mGluR7 also appear to be beneficial [85-87]. These observations suggest that in the absence of agonists, GPCRs can diminish NMDAR calcium fluxes via HINT1. However, in function of the GPCR, its activation can either enhance NMDAR responsiveness or maintain the inhibition of NMDAR function. CNR1 is highly efficacious in counteracting the neuronal damage resulting from NMDAR overactivation, although other GPCRs like DOR, 5HT1AR and mGluR7, could also potentially provide neuroprotection.

\section{Conclusions}

The GPCRs CNR1 and MOR negatively regulate NMDAR responsiveness by interacting with the HINT1 protein. While the control of NMDAR function can be achieved without GPCR activation, many of these agonists were shown to disrupt the GPCR-HINT1 association with NR1 subunits and increase NMDAR responsiveness to activation. Notwithstanding, CNR1 cannabinoids counteracted the negative effects of NMDAR-mediated excitotoxicity and preserved cell viability. As several GPCRs show functional cross-talk with ion channels these interactions might support therapeutic and also undesirable effects of available drugs [88]. Thus, elucidating the role of HINT1 in GPCR regulation of glutamate NMDAR activity will improve our understanding of the mechanisms behind NMDAR-mediated neuronal damage and may provide novel therapeutic targets.

\section{Methods}

\section{Animal studies}

A mouse knock-out strain, 96\% genetic background from 129 mice, with targeted disruption of HINT1 (a gift from I.B. Weinstein/J.B. Wang) and wild-type littermate mice were used for this study. Genotyping was performed on the basis of the protocol described previously [6]. All the procedures for handling and sacrificing animals followed the European Commission guidelines (Council Directive 86/609/EEC) and approved by the Committee on Animal Care at CSIC. NMDA was administered in vivo as described previously [3].

Forced swim test: The test was based on the original version of the forced swim test of Porsolt for mice [89]. Mice were placed in a $5 \mathrm{~L}$ cylinder $(40 \mathrm{~cm}$ high, $25 \mathrm{~cm}$ diameter) filled with $3.5 \mathrm{~L}$ of water, where they swam without the possibility to touch the bottom. Mice were placed in water through a series of four trials of $6 \mathrm{~min}$ each and immobility was recorded during the last $4 \mathrm{~min}$ of each trial using a stopwatch. Immobility was determined when the mouse was only making movements necessary to keep its head above the water and maintained a stationary posture; a stopwatch was started within the first $2 \mathrm{sec}$ immobility was observed.

Chronic constriction injury (CCI): After testing mice for their basal mechanical sensitivity, CCI was performed under isoflurane/oxygen anesthesia using a modification of the Bennett and Xie procedure [90]. Briefly, the sciatic nerve was exposed at the mid-thigh level, proximal to its trifurcation, and two 5/0 braided silk suture ligatures (Lorca Marin, Murcia, Spain, 70014) were tied loosely around the sciatic nerve, 1-2 mm apart. Sham CCI surgery was carried out identically, except that no ligations were placed around the nerve.

\section{Primary cortical cell culture}

Neuron-enriched mouse cerebral cortical cultures were prepared from the brains of embryonic day-16 wild-type 129 and HINT1 knockout mice. Cerebral cortices were dissociated and seeded $\left(1.25 \times 10^{5}\right.$ cells $\left./ \mathrm{cm} 2\right)$ onto multiwell dishes coated with poly-D-lysine. After 3 hours, the culture medium was changed to Neurobasal medium supplemented with B-27, GlutaMAX and antibiotics (100 $\mathrm{IU} / \mathrm{mL}$ Penicillin and $100 \mu \mathrm{g} / \mathrm{mL}$ Streptomycin solution) (Invitrogen, Paisley, UK). From days 5 to 7 in vitro, cytosine arabinoside $(5 \mu \mathrm{M})$ was added to the cultures to eliminate the majority of proliferating non-neuronal cells. Cultures were maintained at $37^{\circ} \mathrm{C}$ in a humidified $5 \% \mathrm{CO} 2$ incubator. In some cases, cells were evaluated after transfection for $72 \mathrm{~h}$, with the concentrated lentiviral vector coding the HINT1 protein cDNA. In a set of experiments, cultures from CNR1 receptor knockout mice, generously donated by Dr. A. Araque [91], were used. 


\section{Measurement of cell death}

Between days 12 and 14 in vitro, cultures were rinsed with serum-free minimal essential medium and treated for $24 \mathrm{~h}$ with NMDA, with or without other drugs. Cell death was quantified by measuring lactate dehydrogenase (LDH, Roche) release into the bathing medium over $24 \mathrm{~h}$ and was expressed as a percentage of cell death induced by a maximally cytotoxic concentration (500 $\mu \mathrm{M})$ of NMDA: (LDH - LDHcontrol)/(LDHNMDA LDHcontrol) $\times 100 \%$.

\section{Immunocytochemistry}

Cells plated onto poly-D-lysine coated $10 \mathrm{~mm}$-glass coverslips were fixed in $4 \%$ paraformaldehyde for 10 min, incubated in $10 \%$ normal goat serum (NGS) and $0.1 \%$ Triton X-100 in phosphate buffer saline (PBS). The cells were immunolabeled with MAP2ab (M1406, Sigma-Aldrich, Madrid, Spain) and for CNR1 receptor (10006590, Cayman Chemical, Ann Arbor, Michigan) for $2 \mathrm{~h}$ at room temperature. The cells were then incubated with Alexa fluor 488 or 594 conjugated secondary antibodies (Invitrogen) and finally with 4,6-diamidino2-phenylindole (DAPI), before mounting in Mowiol solution (Calbiochem, San Diego, CA). Slides were observed with a Leica DMI 6000 inverted fluorescence microscope (Leica Microsistemas S.L.U., Barcelona, Spain). Controls were performed to confirm the specificity of the primary and secondary antibodies.

\section{Lentiviral vector production}

RNAs isolated from mouse brain lysates were reversetranscribed using the SuperScript ${ }^{\circ}$ III First-Strand Synthesis System (Invitrogen) following the manufacturer's instructions. The cDNAs for the murine HINT1 (NM_008248) was then amplified by PCR and subsequently cloned in the pLVTHM "Tet on" inducible vector downstream of the H1 promoter. Cloned inserts were sequenced to verify the integrity of each construct.

Lentiviruses were prepared by cotransfecting $10 \mu \mathrm{g}$ pLVTHM vector (carrying either HINT1 cDNAs or the empty plasmid), $6.5 \mu \mathrm{g}$ second generation packaging plasmid (psPAX2) and $3.5 \mu \mathrm{g}$ envelope plasmid (pMD2.G) into HEK-293T cells. Transfections were carried out with a 1:3 volumetric mix of DNA and FuGENE 6 Transfection Reagent (Roche). Lentivirus-containing supernatants were collected 48 and $72 \mathrm{~h}$ after transfection, filtered through $0.22-\mu \mathrm{m}$-pore nitrocellulose, concentrated by ultracentrifugation, aliquoted, and stored at $-80^{\circ} \mathrm{C}$ until used. The titer of lentivirus was determined by hole-by-dilution titer assay.

\section{Hippocampal slice preparation and electrophysiology} Cortical hippocampal slices were obtained from wildtype 129 and HINT1 knockout mice (13-15 days old).
Animals were decapitated and brains were rapidly removed and placed in ice-cold artificial cerebrospinal fluid containing (in $\mathrm{mM}$ ): $124 \mathrm{NaCl}, 2.7 \mathrm{KCl}, 1.25$ $\mathrm{KH}_{2} \mathrm{PO}_{4}, 2 \mathrm{MgSO}_{4}, 26 \mathrm{NaHCO}_{3}, 10$ glucose, 0.4 ascorbic acid and $2 \mathrm{CaCl}_{2}$, and gassed with $95 \% \mathrm{O} 2 / 5 \% \mathrm{CO} 2(\mathrm{pH}$ 7.3). Slices were incubated for $>45$ minutes at room temperature and then transferred to an immersion recording chamber and superfused with $\mathrm{Mg}^{2+}$-free ice-cold artificial cerebrospinal fluid (ACSF) containing (in mM): 124 $\mathrm{NaCl}, 2.7 \mathrm{KCl}, 1.25 \mathrm{KH}_{2} \mathrm{PO}_{4}, 26 \mathrm{NaHCO}_{3}, 10$ glucose, 4 $\mathrm{CaCl}_{2}, 0.01$ glycine, 0.05 picrotoxin (to block GABA A receptors) and gassed with 95\% O2/5\% CO2 (pH 7.3). Extracellular $\mathrm{Mg}^{2+}$ was omitted to maximize NMDARmediated currents. Cells were visualized under an Olympus BX50WI microscope equipped with infrared and differential interference contrast imaging devices, and with a 40x waterimmersion objective.

Electrophysiological recordings from CA1 pyramidal neurons were made using the whole-cell patch-clamp technique with an internal solution containing (in $\mathrm{mM}$ ): 135 KGluconate, $10 \mathrm{KCl}, 10 \mathrm{HEPES}, 1 \mathrm{MgCl}_{2}$ and $2 \mathrm{ATP}-\mathrm{Na}_{2}$ ( $\mathrm{pH}$ 7.4). Neurons were recorded in voltage-clamp conditions with the membrane potential held at $-70 \mathrm{mV}$. NMDA receptor-mediated currents were isolated in the presence of 6-Cyano-7-nitroquinoxaline-2,3-dione (CNQX; to block AMPA-kainate receptors; $20 \mu \mathrm{M})$. When indicated, the purified r-HINT1 protein was included in the internal solution at a final concentration of $150 \mathrm{nM}$. Signals were fed to a Pentium-based PC through a DigiData 1440A interface board. Signals were filtered at $1 \mathrm{KHz}$ and acquired at $10 \mathrm{KHz}$ sampling rate. The pCLAMP 10.2 (Axon instruments, Sunnyvale, CA) software was used for data acquisition and storage.

\section{Immunoprecipitation and Western blotting}

Preparation of membrane from cortical cell cultures and immunoprecipitation of NR1 subunits was performed as described previously [3]. The immunocomplexes were recovered and proteins were resolved by SDS/polyacrylamide gel electrophoresis (PAGE). The separated proteins were then transferred onto $0.2 \mu \mathrm{m}$ polyvinylidene difluoride (PVDF) membranes (BioRad 162-0176), probed with the primary antibodies to HINT1 (Abnova H00003094-A01. Abyntek, Spain) and CNR1 (C terminal sequence 461-472; Cayman Chemical, Mi, USA, 10006590), and detected using secondary antibodies conjugated to horseradish peroxidase. Antibody binding was visualized by chemiluminescence and recorded with a Chemilmager IS-5500 (Alpha Innotech, San Leandro, California). Densitometry was performed using Quantity One Software (BioRad) and expressed as the mean \pm SEM of the integrated volume (average optical density of the pixels within the object area/mm2). 


\section{Enzymatic activity}

The Pep Tag protein kinase A assay (Promega, Madison, WI, USA) was used for assessing total PKA enzymatic activity according to the manufacturer's instructions. Briefly, brain lysates were prepared using RIPA buffer at $4{ }^{\circ} \mathrm{C}$. The homogenate was then centrifuged at $18,000 \times g$ for $15 \mathrm{~min}$ at $4^{\circ} \mathrm{C}$. The supernatants were incubated for $2 \mathrm{~min}$ at $30^{\circ} \mathrm{C}$ and for $30 \mathrm{~min}$ at $30^{\circ} \mathrm{C}$ with the specific substrate in the presence of activating solution. The reaction was stopped at $95^{\circ} \mathrm{C}$ for $10 \mathrm{~min}$. The PKA-induced phosphorylation specifically changes the net charge of the fluorescent peptide substrate from +1 to -1 . Consequently peptides were separated according to their net charges via electrophoresis in $0.8 \%$ agarose in $50 \mathrm{mM}$ Tris- $\mathrm{HCl}(\mathrm{pH} 8.0)$ in a horizontal gel at $100 \mathrm{~V}$ for $15 \mathrm{~min}$. The phosphorylated peptide migrated towards the anode and the nonphosphorylated peptide to the cathode.

\section{Zinc-microfluorescence imaging in mouse cortical slices} Coronal mouse frontal cortex slices $(200 \mu \mathrm{m} ; 2.50-1.50$ $\mathrm{mm}$ to bregma) from WT and $\mathrm{HINT}_{1}{ }^{-/-}$mice were oxygenated and preloaded with $50 \mu \mathrm{M}$ of the cell-permeable Newport Green diacetate (50 $\mu \mathrm{M}$; N7991, Invitrogen), $0.1 \%$ pluronic acid and $0.5 \%$ dimethyl sulfoxide for $1 \mathrm{~h}$ as described elsewhere [30]. The permeated probe remains trapped and that remaining in the extracellular millieu was removed before adding the substances under study and performing Intracellular $\mathrm{Zn}^{2+}$ imaging. The effects of the following compounds were assayed: NMDA; the NMDAR antagonist MK801; the NOS/NO inhibitor LNNA (Tocris, UK, 0664). Images were obtained by confocal microscopy through a $10 \times 0.4 \mathrm{HC}$ PL APO objective on a Leica DMIII 6000 CS confocal fluorescence microscope equipped with a TCS SP5 scanning laser (excitation, $488 \mathrm{~nm}$; emission, 498-520 nm). The size and resolution of the captured images were identical and before data analysis it was verified that within the area under study variations in pixel luminosity were normally distributed (Systat Software, Inc., Erkrath, Germany). For each concentration of NMDA and animal group (WT and $\mathrm{HINT}^{-/-}$) differences of luminosity means between control and NMDA-treated images were computed (AlphaEase FC Software, San Leandro, CA, USA). The data were analyzed to determine correlation coefficients and 95\% of confidence intervals of WT and HINT1 $^{-/-}$groups and plotted (Sigmaplot/Sigmastat v12, Erkrath, Germany). The images were color indexed and presented in pseudocolor [31].

\section{Spectrophotometric detection of zinc released from cortical synaptosomes}

Samples $(0.5 \mathrm{~mL}$ total volume) were prepared by adding $100 \mu \mathrm{L}$ of cortical membrane suspension, vehicle or the NO donor (S)-Nitroso-N-acetylpenicillamine (SNAP) to
$400 \mu \mathrm{L}$ of Hepes buffer (25 mM; pH 7.8; treated with Chelex-100 resin (BioRad). The zinc ion releasing effect of SNAP on brain synaptosomes reached a maximum when used at $100 \mu \mathrm{M}$ for $30 \mathrm{~min}$ [30]. Calibration samples were prepared from $\mathrm{ZnCl}_{2}$ (100 mM) solution (Sigma 39059) and Hepes buffer. For blanks, the metal solution was substituted with Chelex-100-treated water. Complexation was initiated by the addition of the zinc chelator Zincon (Sigma \#96440) (stock solution $1.6 \mathrm{mM}$ in $\mathrm{NaOH} 1 \mathrm{M}$ ) to reach a final concentration of $40 \mu \mathrm{M}$. Absorption spectra $(600 \mathrm{~nm})$ were recorded after $20 \mathrm{~min}$ of sample incubation at room temperature (RT) on a BioChrom Ultrospec 2100 spectrophotometer (Cambridge, UK).

\section{Drugs and primary antibodies}

$\mathrm{R}(+)$-Win 55212 was purchased from Sigma-Aldrich (Madrid, Spain), N-Methyl-d-aspartate (NMDA), Ly320135, JTE907, MK801, LNNA, DAMGO and AP5 were obtained from Tocris (Abingdon, UK). Morphine sulfate was from Merck (Darmstadt, Germany). Recombinant HINT1 protein was obtained as previously described $[3,6]$. The antibodies used in this study were: MAP2ab (M1406, Sigma-Aldrich, Madrid, Spain), HINT1 (Abnova H00003094-A01, Abyntek, Spain) and CNR1 receptor (10006590, Cayman Chemical, Ann Arbor, Michigan) NMDAR1 (Abcam ab1880); $\mathrm{Ca}^{2+} / \mathrm{cal}-$ modulin-dependent protein kinase II (BD 611292); Phospho- $\mathrm{Ca}^{2+} /$ calmodulin-dependent protein kinase II (CaMKII Thr286, Cell Signaling 3361).

\section{Data analysis}

Data were expressed as mean \pm S.E.M. ANOVA, followed by the Student-Newman-Keuls test (SigmaStat, SPSS Science Software, Erkrath, Germany) was performed and significance was defined as $P<0.05$.

\section{Abbreviations \\ CCl: Chronic constriction injury; CNR1: Cannabinoid receptor type 1; GPCRs: G protein-coupled receptors; HINT1: Histidine triad nucleotide-binding protein 1; LDH: Lactate dehydrogenase; MOR: Mu-opioid receptor; NMDA: N-methyl- D-aspartate; PAGE: SDS/polyacrylamide gel electrophoresis; PKC: Protein \\ kinase C; PKCi: Protein kinase C-interacting protein..}

\section{Competing interests}

The authors declare that they have no competing interests.

\section{Authors' contributions}

AVS, PSB and MRM performed the experiments. JG and PSB conceived and designed the study and wrote the paper. All authors read and approved the final manuscript.

\section{Acknowledgements}

We would like to thank Gabriela de Alba, Concha Bailón and Marta Gomez for their excellent technical assistance. Funding: This research was supported by "Plan Nacional de Drogas 2011-014 (JG) \& MINECO, SAF-2012/34991 (JG) and FIS PI11/01704 (PS-B)".

Received: 22 August 2013 Accepted: 19 September 2013

Published: 5 October 2013 


\section{References}

1. Lu WY, Xiong ZG, Lei S, Orser BA, Dudek E, Browning MD, et al: G-proteincoupled receptors act via protein kinase $C$ and Src to regulate NMDA receptors. Nat Neurosci 1999, 2:331-338.

2. Salter MW, Kalia LV: Src kinases: a hub for NMDA receptor regulation. Nat Rev Neurosci 2004, 5:317-328.

3. Rodríguez-Muñoz M, Sánchez-Blázquez P, Vicente-Sánchez A, Berrocoso E, Garzón J: The Mu-Opioid receptor and the NMDA receptor associate in PAG neurons: implications in pain control. Neuropsychopharmacology 2012, 37:338-349.

4. Chen L, Huang LY: Sustained potentiation of NMDA receptor-mediated glutamate responses through activation of protein kinase $\mathrm{C}$ by a $\mathrm{m}$ opioid. Neuron 1991, 7:319-326.

5. Sánchez-Blázquez P, Rodríguez-Muñoz M, Vicente-Sánchez A, Garzón J: Cannabinoid receptors couple to NMDA receptors to reduce the production of $\mathrm{NO}$ and the mobilization of zinc induced by glutamate. Antioxid Redox Signal 2013. 10.1089/ars.2012.5100.

6. Rodríguez-Muñoz M, Sánchez-Blázquez P, Vicente-Sánchez A, Bailón C, Martín-Aznar B, Garzón J: The histidine triad nucleotide-binding protein 1 supports mu-opioid receptor-glutamate NMDA receptor cross-regulation. Cell Mol Life Sci 2011, 68:2933-2949.

7. Guang W, Wang H, Su T, Weinstein IB, Wang JB: Role of mPKCl, a novel $\mathrm{mu}$-opioid receptor interactive protein, in receptor desensitization, phosphorylation, and morphine-induced analgesia. Mol Pharmacol 2004, 66:1285-1292.

8. Liu XJ, Salter MW: Glutamate receptor phosphorylation and trafficking in pain plasticity in spinal cord dorsal horn. Eur J Neurosci 2010, 32:278-289.

9. Liu Q, Bhat M, Bowen WD, Cheng J: Signaling pathways from cannabinoid receptor-1 activation to inhibition of N-methyl-D-aspartic acid mediated calcium influx and neurotoxicity in dorsal root ganglion neurons. J Pharmacol Exp Ther 2009, 331:1062-1070.

10. Zhuang SY, Bridges D, Grigorenko E, McCloud S, Boon A, Hampson RE, et al: Cannabinoids produce neuroprotection by reducing intracellular calcium release from ryanodine-sensitive stores. Neuropharmacology 2005, 48:1086-1096.

11. Li Q Yan $\mathrm{H}$, Wilson WA, Swartzwelder HS. Modulation of NMDA and AMPA-mediated synaptic transmission by CB1 receptors in frontal cortical pyramidal cells. Brain Res 2010, 1342:127-137.

12. Hohmann AG, Briley EM, Herkenham M: Pre- and postsynaptic distribution of cannabinoid and mu opioid receptors in rat spinal cord. Brain Res 1999, 822:17-25

13. Ong WY, Mackie K: A light and electron microscopic study of the CB1 cannabinoid receptor in the primate spinal cord. J Neurocytol 1999, 28:39-45.

14. Salio C, Fischer J, Franzoni MF, Conrath M: Pre- and postsynaptic localizations of the CB1 cannabinoid receptor in the dorsal horn of the rat spinal cord. Neuroscience 2002, 110:755-764.

15. Kofalvi A, Rodrigues RJ, Ledent C, Mackie K, Vizi ES, Cunha RA, et al: Involvement of cannabinoid receptors in the regulation of neurotransmitter release in the rodent striatum: a combined immunochemical and pharmacological analysis. J Neurosci 2005, 25:2874-2884.

16. Rodriguez JJ, Mackie K, Pickel VM: Ultrastructural localization of the CB1 cannabinoid receptor in mu-opioid receptor patches of the rat Caudate putamen nucleus. J Neurosci 2001, 21:823-833.

17. Marchalant Y, Cerbai F, Brothers HM, Wenk GL: Cannabinoid receptor stimulation is anti-inflammatory and improves memory in old rats. Neurobiol Aging 2008, 29:1894-1901

18. Garzón J, de la Torre-Madrid E, Rodríguez-Muñoz M, Vicente-Sánchez A, Sánchez-Blázquez P: Gz mediates the long-lasting desensitization of brain $\mathrm{CB} 1$ receptors and is essential for cross-tolerance with morphine. Mol Pain 2009, 5:11.

19. Fan $\mathrm{N}$, Yang $\mathrm{H}$, Zhang J, Chen C: Reduced expression of glutamate receptors and phosphorylation of CREB are responsible for in vivo Delta9-THC exposure-impaired hippocampal synaptic plasticity. J Neurochem 2010, 112:691-702.

20. Brenner C: Hint, Fhit, and GalT: function, structure, evolution, and mechanism of three branches of the histidine triad superfamily of nucleotide hydrolases and transferases. Biochemistry 2002, 41:9003-9014.

21. Lima CD, Klein MG, Weinstein IB, Hendrickson WA: Three-dimensional structure of human protein kinase $C$ interacting protein 1 , a member of the HIT family of proteins. Proc Natl Acad Sci U S A 1996, 93:5357-5362.
22. McDonald JR, Groschel-Stewart U, Walsh MP: Properties and distribution of the protein inhibitor (Mr 17,000) of protein kinase C. Biochem J 1987, 242:695-705.

23. Huebner K, Saldivar JC, Sun J, Shibata H, Druck T: Hits, Fhits and Nits: beyond enzymatic function. Adv Enzyme Regul 2011, 51:208-217.

24. Weiske J, Huber O: The histidine triad protein Hint1 triggers apoptosis independent of its enzymatic activity. J Biol Chem 2006, 281:27356-27366.

25. Li H, Zhang Y, Su T, Santella RM, Weinstein IB: Hint1 is a haplo-insufficient tumor suppressor in mice. Oncogene 2006, 25:713-721.

26. Huber O, Weiske J: Beta-catenin takes a HIT. Cell Cycle 2008, 7:1326-1331.

27. Linde $\mathrm{Cl}$, Feng $\mathrm{B}$, Wang JB, Golovina VA: Histidine triad nucleotide-binding protein 1 (HINT1) regulates $\mathrm{Ca}(2+)$ signaling in mouse fibroblasts and neuronal cells via store-operated $\mathrm{Ca}(2+)$ entry pathway. Am J Physiol Cell Physiol 2013, 304:C1098-C1104

28. Ajit SK, Ramineni S, Edris W, Hunt RA, Hum WT, Hepler JR, et al: RGSZ1 interacts with protein kinase $\mathrm{C}$ interacting protein $\mathrm{PKCl}-1$ and modulates mu opioid receptor signaling. Cell Signal 2007, 19:723-730.

29. Rodríguez-Muñoz M, Torre-Madrid E, Sánchez-Blázquez P, Wang JB, Garzón J: NMDAR-nNOS generated zinc recruits PKCgamma to the HINT1-RGS17 complex bound to the $\mathrm{C}$ terminus of mu-opioid receptors. Cell Signal 2008, 20:1855-1864.

30. Rodríguez-Muñoz M, Torre-Madrid E, Sánchez-Blázquez P, Garzón J: NOreleased zinc supports the simultaneous binding of Raf-1 and PKCgamma cysteine-rich domains to HINT1 protein at the mu-opioid receptor. Antioxid Redox Signal 2011, 14:2413-2425.

31. Sánchez-Blázquez P, Rodríguez-Muñoz M, Bailón C, Garzón J: GPCRs promote the release of zinc ions mediated by nNOS/NO and the Redox transducer RGSZ2 protein. Antioxid Redox Signal 2012, 17:1163-1177.

32. Garzón J, Rodríguez-Muñoz M, Sánchez-Blazquez P: Direct association of mu-opioid and NMDA glutamate receptors supports their crossregulation: molecular implications for opioid tolerance. Curr Drug Abuse Rev 2012, 5:199-226.

33. Rodríguez-Muñoz M, Garzón J: Nitric oxide and zinc-mediated protein assemblies involved in mu opioid receptor signaling. Mol Neurobiol 2013. 10.1007/s12035-013-8465-z.

34. Inoue M, Mishina M, Ueda H: Locus-specific rescue of GluRe1 NMDA receptors in mutant mice identifies the brain regions important for morphine tolerance and dependence. J Neurosci 2003, 23:6529-6536.

35. Trujillo KA, Akil H: Inhibition of morphine tolerance and dependence by the NMDA receptor antagonist MK-801. Science 1991, 251:85-87.

36. Lipton SA: Paradigm shift in neuroprotection by NMDA receptor blockade: memantine and beyond. Nat Rev Drug Discov 2006, 5:160-170

37. Mechri A, Saoud M: Khiari G, d'Amato T, Dalery J, Gaha L: Glutaminergic hypothesis of schizophrenia: clinical research studies with ketamine. Encéphale 2001, 27:53-59.

38. Maeng S: Zarate Jr CA: The role of glutamate in mood disorders: results from the ketamine in major depression study and the presumed cellular mechanism underlying its antidepressant effects. Curr Psychiatry Rep 2007, 9:467-474

39. Sigtermans MJ, van Hilten JJ, Bauer MC, Arbous MS, Marinus J, Sarton EY, et al Ketamine produces effective and long-term pain relief in patients with Complex Regional Pain Syndrome Type 1. Pain 2009, 145:304-311.

40. Chapman V, Haley JE, Dickenson AH: Electrophysiologic analysis of preemptive effects of spinal opioids on $\mathrm{N}$-methyl-D-aspartate receptormediated events. Anesthesiology 1994, 81:1429-1435.

41. Khaspekov LG, Brenz Verca MS, Frumkina LE, Hermann H, Marsicano G, Lutz B: Involvement of brain-derived neurotrophic factor in cannabinoid receptor-dependent protection against excitotoxicity. Eur J Neurosci 2004, 19:1691-1698.

42. Kim SH, Won SJ, Mao XO, Jin K, Greenberg DA: Molecular mechanisms of cannabinoid protection from neuronal excitotoxicity. Mol Pharmacol 2006, 69:691-696.

43. Herkenham M, Lynn AB, Little MD, Johnson MR, Melvin LS, de Costa BR, et al Cannabinoid receptor localization in brain. Proc Natl Acad Sci U S A 1990, 87:1932-1936

44. Twitchell W, Brown S, Mackie K: Cannabinoids inhibit N- and P/Q-type calcium channels in cultured rat hippocampal neurons. J Neurophysiol 1997, 78:43-50.

45. Sensi SL, Jeng JM: Rethinking the excitotoxic ionic milieu: the emerging role of $\mathrm{Zn}(2+)$ in ischemic neuronal injury. Curr Mol Med 2004, 4:87-111.

46. Angulo MC, Kozlov AS, Charpak S, Audinat E: Glutamate released from glial cells synchronizes neuronal activity in the hippocampus. J Neurosci 2004, 24:6920-6927. 
47. Fellin T, Pascual O, Gobbo S, Pozzan T, Haydon PG, Carmignoto G: Neuronal synchrony mediated by astrocytic glutamate through activation of extrasynaptic NMDA receptors. Neuron 2004, 43:729-743.

48. Perea G, Araque A: Properties of synaptically evoked astrocyte calcium signal reveal synaptic information processing by astrocytes. J Neurosci 2005, 25:2192-2203.

49. Makhinson M, Chotiner JK, Watson JB, O'Dell TJ: Adenylyl cyclase activation modulates activity-dependent changes in synaptic strength and $\mathrm{Ca} 2+/$ calmodulin-dependent kinase II autophosphorylation. J Neurosci 1999, 19:2500-2510.

50. Valdenaire O, Maus-Moatti M, Vincent JD, Mallet J, Vernier P: Retinoic acid regulates the developmental expression of dopamine D2 receptor in rat striatal primary cultures. J Neurochem 1998, 71:929-936.

51. Roth BL, Hamblin MW, Ciaranello RD: Developmental regulation of 5-HT2 and 5-HT1c mRNA and receptor levels. Brain Res Dev Brain Res 1991, 58:51-58.

52. Maloteaux JM, Octave JN, Laterre EC, Laduron PM: Down-regulation of $3 \mathrm{H}-$ lofentanil binding to opiate receptors in different cultured neuronal cells. Naunyn Schmiedebergs Arch Pharmacol 1989, 339:192-199.

53. Sánchez-Blázquez P, Rodríguez-Muñoz M, Berrocoso E, Garzón J: The plasticity of the association between mu-opioid receptor and glutamate ionotropic receptor $\mathrm{N}$ in opioid analgesic tolerance and neuropathic pain. Eur J Pharmacol 2013. 10.1016/j.ejphar.2013.01.066.

54. Kim E, Sheng M: PDZ domain proteins of synapses. Nat Rev Neurosci 2004, 5:771-781.

55. Sans N, Wang PY, Du Q, Petralia RS, Wang YX, Nakka S, et al: mPins modulates PSD-95 and SAP102 trafficking and influences NMDA receptor surface expression. Nat Cell Biol 2005, 7:1179-1190.

56. Pei L, Lee FJ, Moszczynska A, Vukusic B, Liu F: Regulation of dopamine D1 receptor function by physical interaction with the NMDA receptors. J Neurosci 2004, 24:1149-1158.

57. Perroy J, Raynaud F, Homburger V, Rousset MC, Telley L, Bockaert J, et al: Direct interaction enables cross-talk between ionotropic and group I metabotropic glutamate receptors. J Biol Chem 2008, 283:6799-6805.

58. Hardingham GE, Bading H: Synaptic versus extrasynaptic NMDA receptor signalling: implications for neurodegenerative disorders. Nat Rev Neurosci 2010, 11:682-696.

59. Rajkowska G: Cell pathology in mood disorders. Semin Clin Neuropsychiatry 2002, 7:281-292.

60. Herberth M, Koethe D, Levin Y, Schwarz E, Krzyszton ND, Schoeffmann S, et al: Peripheral profiling analysis for bipolar disorder reveals markers associated with reduced cell survival. Proteomics 2011, 11:94-105.

61. Jackson KJ, Wang JB, Barbier E, Chen X, Damaj MI: Acute behavioral effects of nicotine in male and female HINT1 knockout mice. Genes Brain Behav 2012. 10.1111/j.1601-183X.2012.00827.x.

62. Marsicano G, Goodenough S, Monory K, Hermann H, Eder M, Cannich A, et al: CB1 cannabinoid receptors and on-demand defense against excitotoxicity Science 2003, 302:84-88.

63. Jin $L Q$, Wang HY, Friedman E: Stimulated $D(1)$ dopamine receptors couple to multiple Galpha proteins in different brain regions. J Neurochem 2001, 78:981-990

64. Johnson-Farley NN, Kertesy SB, Dubyak GR, Cowen DS: Enhanced activation of Akt and extracellular-regulated kinase pathways by simultaneous occupancy of Gq-coupled 5-HT2A receptors and Gs-coupled 5-HT7A receptors in PC12 cells. J Neurochem 2005, 92:72-82.

65. Sánchez-Blázquez P, Gómez-Serranillos P, Garzón J: Agonists determine the pattern of $\mathrm{G}$-protein activation in mu-opioid receptor-mediated supraspinal analgesia. Brain Res Bull 2001, 54:229-235.

66. Wang HY, Undie AS, Friedman E: Evidence for the coupling of Gq protein to D1-like dopamine sites in rat striatum: possible role in dopaminemediated inositol phosphate formation. Mol Pharmacol 1995, 48:988-994.

67. Garzón J, Rodríguez-Díaz M, López-Fando A, García-España A, SánchezBlázquez P: Glycosylated phosducin-like protein long regulates opioid receptor function in mouse brain. Neuropharmacology 2002, 42:813-828.

68. Guo W, Zou S, Guan Y, Ikeda T, Tal M, Dubner R, et al: Tyrosine phosphorylation of the NR2B subunit of the NMDA receptor in the spinal cord during the development and maintenance of inflammatory hyperalgesia. J Neurosci 2002, 22:6208-6217.

69. Peters S, Koh J, Choi DW: Zinc selectively blocks the action of N-methyl-Daspartate on cortical neurons. Science 1987, 236:589-593.

70. Williams K: Separating dual effects of zinc at recombinant N-methyl-Daspartate receptors. Neurosci Lett 1996, 215:9-12.
71. Lieberman DN, Mody I: Regulation of NMDA channel function by endogenous $\mathrm{Ca}(2+)$-dependent phosphatase. Nature 1994, 369:235-239.

72. Chakravarthy B, Morley P, Whitfield J: Ca2+-calmodulin and protein kinase Cs: a hypothetical synthesis of their conflicting convergences on shared substrate domains. Trends Neurosci 1999, 22:12-16.

73. Lau LF, Huganir RL: Differential tyrosine phosphorylation of N-methyl-Daspartate receptor subunits. J Biol Chem 1995, 270:20036-20041.

74. Zheng F, Gingrich MB, Traynelis SF, Conn PJ: Tyrosine kinase potentiates NMDA receptor currents by reducing tonic zinc inhibition. Nat Neurosci 1998, 1:185-191.

75. Choe ES, Shin EH, Wang JQ: Inhibition of protein phosphatase $2 \mathrm{~B}$ upregulates serine phosphorylation of $\mathrm{N}$-methyl-D-aspartate receptor NR1 subunits in striatal neurons in vivo. Neurosci Lett 2005, 384:38-43.

76. Goebel-Goody SM, Baum M, Paspalas CD, Fernandez SM, Carty NC, Kurup P, et al: Therapeutic implications for striatal-enriched protein tyrosine phosphatase (STEP) in neuropsychiatric disorders. Pharmacol Rev 2012, 64:65-87.

77. Zhang S, Ehlers MD, Bernhardt JP, Su CT, Huganir RL: Calmodulin mediates calcium-dependent inactivation of $\mathrm{N}$-methyl-D-aspartate receptors. Neuron 1998, 21:443-453.

78. Krupp JJ, Vissel B, Thomas CG, Heinemann SF, Westbrook GL: Interactions of calmodulin and alpha-actinin with the NR1 subunit modulate Ca2+-dependent inactivation of NMDA receptors. J Neurosci 1999, 19:1165-1178.

79. Merrill MA, Malik Z, Akyol Z, Bartos JA, Leonard AS, Hudmon A, et al: Displacement of alpha-actinin from the NMDA receptor NR1 C0 domain by Ca2+/calmodulin promotes CaMKII binding. Biochemistry 2007, 46:8485-8497.

80. Hisatsune C, Umemori H, Inoue T, Michikawa T, Kohda K, Mikoshiba K, et al: Phosphorylation-dependent regulation of N-methyl-D-aspartate receptors by calmodulin. J Biol Chem 1997, 272:20805-20810.

81. Tingley WG, Ehlers MD, Kameyama K, Doherty C, Ptak JB, Riley CT, et al: Characterization of protein kinase $A$ and protein kinase $C$ phosphorylation of the N-methyl-D-aspartate receptor NR1 subunit using phosphorylation site-specific antibodies. J Biol Chem 1997 272:5157-5166.

82. Lin MT: Heatstroke-induced cerebral ischemia and neuronal damage. Involvement of cytokines and monoamines. Ann N Y Acad Sci 1997, 813:572-580.

83. Chang CK, Chang CP, Chiu WT, Lin MT: Prevention and repair of circulatory shock and cerebral ischemia/injury by various agents in experimental heatstroke. Curr Med Chem 2006, 13:3145-3154.

84. Chen ZC, Kuo JR, Huang YP, Lin MT: Mu-opioid receptor blockade protects against circulatory shock and cerebral ischemia during heatstroke. J Cardiovasc Pharmacol 2005, 46:754-760.

85. Chang CP, Chen SH, Lin MT: Ipsapirone and ketanserin protects against circulatory shock, intracranial hypertension, and cerebral ischemia during heatstroke. Shock 2005, 24:336-340.

86. Gu Z, Liu W, Wei J, Yan Z: Regulation of N-methyl-D-aspartic acid (NMDA) receptors by metabotropic glutamate receptor 7. J Biol Chem 2012, 287:10265-10275

87. He X, Sandhu HK, Yang Y, Hua F, Belser N, Kim DH, et al: Neuroprotection against hypoxia/ischemia: delta-opioid receptor-mediated cellular/ molecular events. Cell Mol Life Sci 2012.

88. Dingledine R, Borges K, Bowie D, Traynelis SF: The glutamate receptor ion channels. Pharmacol Rev 1999, 51:7-61.

89. Porsolt RD, Bertin A, Jalfre M: Behavioral despair in mice: a primary screening test for antidepressants. Arch Int Pharmacodyn Ther 1977, 229:327-336.

90. Bennett GJ, Xie YK: A peripheral mononeuropathy in rat that produces disorders of pain sensation like those seen in man. Pain 1988, 33:87-107.

91. Navarrete M, Araque A: Endocannabinoids mediate neuron-astrocyte communication. Neuron 2008, 57:883-893.

doi:10.1186/1756-6606-6-42

Cite this article as: Vicente-Sánchez et al:: HINT1 protein cooperates with cannabinoid 1 receptor to negatively regulate glutamate NMDA receptor activity. Molecular Brain 2013 6:42 